\title{
Managing Multiple Sclerosis: Treatment Initiation, Modification, and Sequencing
}

\author{
Mark S. Freedman, Daniel Selchen, Alexandre Prat, Paul S. Giacomini
}

\begin{abstract}
Recent therapeutic advances in the management of multiple sclerosis (MS) have raised questions about the selection of appropriate patient candidates for various treatments and, if the plan is to move from one treatment to another, the appropriate sequencing of these therapies. The selected approach should provide optimal disease management without limiting future therapeutic options based on safety concerns, and recognize potential future treatments and the possibility of combination therapies. Additional challenges include incorporation of patient needs and preferences into the overall therapeutic approach, in order to ensure optimal outcomes in the short and long term. The objective of this manuscript is to provide an overview of what is currently known regarding the impact of various therapies for MS on future therapeutic choices (sequencing). In this context, we reviewed the available evidence in support of various treatments and, based on the presence of disease activity, suggested a scheme for switching or escalating therapy with the main focus on sequencing of therapeutic approaches.
\end{abstract}

RÉSUMÉ: Prise en charge de la sclérose en plaques du début d'un traitement à sa modification : considérations par rapport aux séquences thérapeutiques envisagées. Des avancées thérapeutiques récentes dans la prise en charge de la sclérose en plaques (SP) ont soulevé des questions relatives à la sélection appropriée de patients en regard avec divers traitements. Dans l'hypothèse où l'on opterait pour une série de traitements, il y a aussi lieu de se questionner quant à la séquence la plus appropriée. À cet égard, toute approche thérapeutique devrait pouvoir fournir une prise en charge optimale de la maladie sans pour autant exclure d'autres traitements futurs en raison de préoccupations en matière de sécurité. Toute approche thérapeutique devrait aussi reconnaitre l'existence de traitements potentiels et la possibilité de combiner des traitements. D'autres défis additionnels incluent notamment le fait d'incorporer les besoins et préférences des patients dans une approche d'ensemble afin d'assurer, à court et à long terme, une évolution optimale de leur état de santé. L'objectif de cette étude est donc de fournir un aperçu de l'état actuel des connaissances en ce qui a trait aux impacts des divers traitements de la SP quant à de futurs choix thérapeutiques (leur séquence). Dans cette perspective, nous nous sommes penchés sur des données probantes au sujet de ces divers traitements. Une fois des cas de SP détectés, nous avons suggéré un plan de modification ou d'intensification des traitements en mettant l'accent sur leur séquence.

Keywords: Multiple sclerosis, Long-term outcome, Relapsing remitting

doi:10.1017/cjn.2018.17

Can J Neurol Sci. 2018; 45: 489-503

\section{INTRODUCTION}

Multiple sclerosis (MS) is a chronic demyelinating disease of the central nervous system (CNS) characterized by inflammation, demyelination, and neurodegeneration. ${ }^{1,2}$ The disease is heterogeneous in its clinical manifestation and progression. The key pathological mechanism involves infiltration of autoreactive immune cells into the CNS where, with varying degrees of severity, they cause demyelination, gliosis, neuronal loss, and eventually cerebral atrophy. ${ }^{1-4}$

Since the publication of the Canadian MS Working Group Updated Recommendations regarding treatment optimization in MS, ${ }^{5}$ several new therapies have become available while others are imminent. The advent of new therapeutic options has created a need for guidance on treatment sequencing, including algorithms to assist clinicians when deciding on therapeutic approaches for a particular patient. The selected approach should provide optimal disease management while not limiting future therapeutic options based on safety concerns. It should also recognize potential future treatments and the possibility of combinations.

Taking this into consideration, we developed an approach that assesses patients' risk for imminent progression (low vs. high) and then evaluates their response to treatment (Figure 1) as outlined by Freedman et al. ${ }^{5}$

\section{TREATMENT INITIATION}

The clinical course of MS is highly variable, ranging from patients with relatively mild disease even years after the diagnosis to those with an early aggressive course and rapid accumulation of disability. Before initiating MS therapy, clinicians must consider the nature of the disease and long-term treatment plan, which is likely to be influenced by patient- and disease-related characteristics. Depending on the anticipated course of the disease, two different therapeutic approaches can be considered for treatment

From the Division of Neurology, Department of Medicine, University of Ottawa and the Ottawa Hospital Research Institute, Ottawa, ON, Canada (MSF); Montreal Neurological Institute, McGill University, Montréal, QC, Canada (PSG); CRCHUM and Department of Neuroscience, Faculty of Medicine, Université de Montréal, Montréal, QC, Canada (AP); St. Michael's Hospital, University of Toronto, Toronto, ON, Canada (DS).

Received June 5, 2017. Final Revisions Submitted December 22, 2017. Date of ACCEPTANCE JANUARY 18, 2018.

Correspondence to: Mark S. Freedman, The Ottawa Hospital - General Campus, 501 Smyth Road, Ottawa, ON, Canada, K1H 8L6. Email: mfreedman@toh.ca 


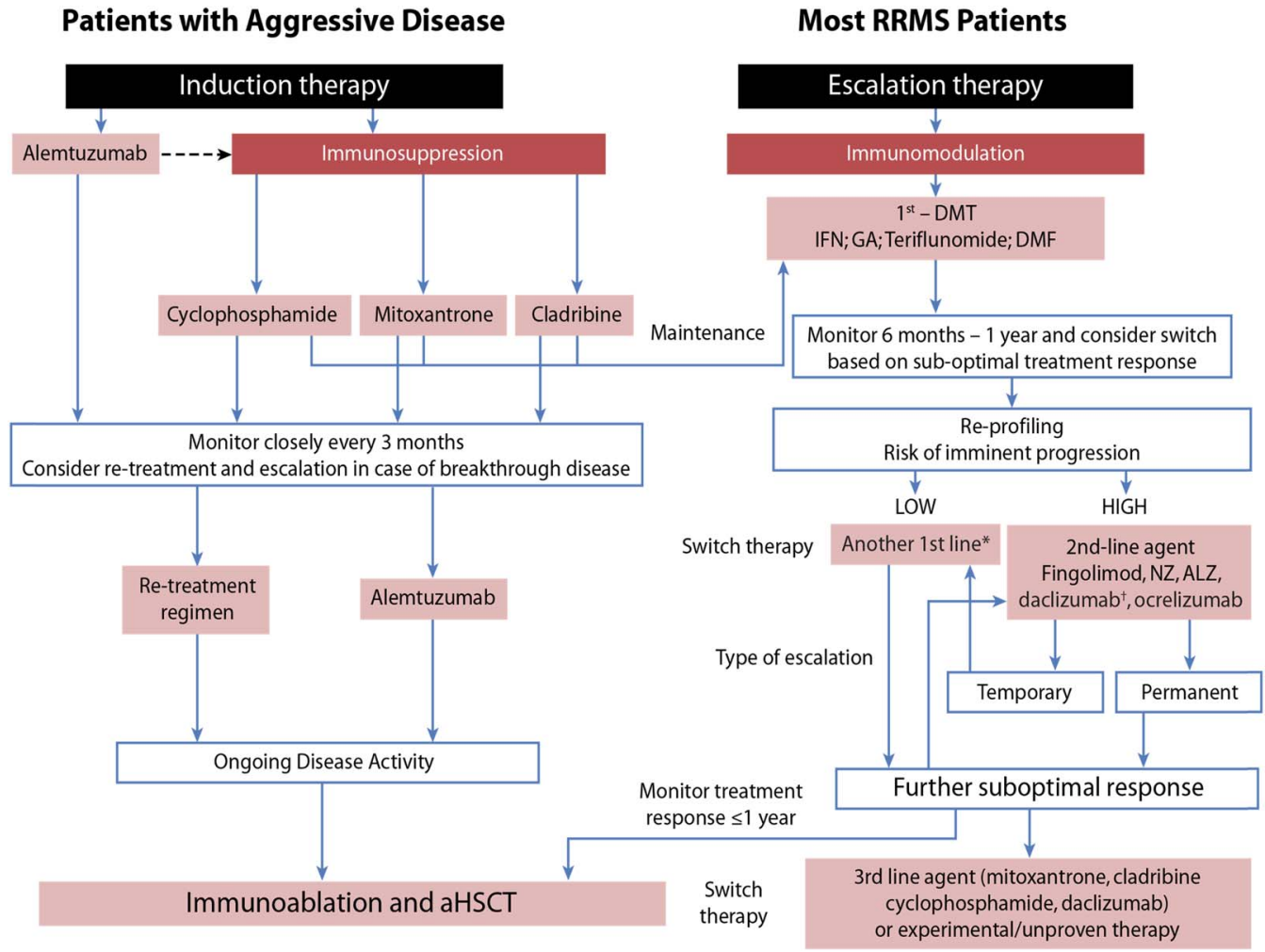

Figure 1: Sequencing algorithm. No monitoring and laboratory tests at baseline is requested when initiating or switching to glatiramer acetate (GA) and only thyroid testing, complete blood count and liver function test are necessary when starting or lateral switching patients to interferons (IFNs). *Tolerability is often a reason for a lateral switch. †Daclizumab was voluntarily removed from the market March 2, 2018 due to safety concerns. ${ }^{102}$ aHSCT $=$ autologous hematopoietic stem-cell transplantation; ALZ=alemtuzumab; $D M F=$ dimethyl fumarate $; D M T=$ disease-modifying therapies $; M S=$ multiple sclerosis; $N Z=$ natalizumab; $R R M S=$ relapsing remitting multiple sclerosis. Adapted with permission from Freedman et al ${ }^{5}$ and Rush et al. ${ }^{9}$

initiation: induction and escalation. In addition, as the treatment course may involve more than one agent, the optimal initial treatment should be one that does not limit subsequent therapeutic options.

Aggressive MS, affecting about $10 \%$ of MS patients, can be defined as disease leading to disability within 5 years from symptom onset and rapid transition to secondary progressive MS. ${ }^{6,7}$ As early aggressive disease activity drives long-term disability, it is extremely important that it be identified quickly and treated effectively (Table 1). ${ }^{8,9}$ Treatment of aggressive MS requires an aggressive approach (Figure 1) usually using agents more capable of eliminating disease-causing cells (immunosuppressive therapy) instead of those that only alter their functioning (immunomodulation) or prevent them from entering the brain without altering either their function or their numbers (anti-trafficking agents).

The selection of treatment(s) for even typical relapsing multiple sclerosis (RMS) has become very challenging because of the number and availability of therapies, including new agents with more complex mechanisms of action and greater risks of adverse effects that may also impact subsequent therapies. Although much remains unknown about the effects of moving between immunosuppressive and other disease-modifying therapies (DMTs), factors such as presence of co-morbidities, desire for pregnancy, previous use of other immunosuppressants (for MS or other conditions), John Cunningham virus (JCV) antibody seropositivity, geographical parameters, health insurance coverage, and patient/neurologist preferences can influence the treatment selection and might also inform the sequencing of therapies. As the order in which treatments are used might predispose patients to increased long-term toxicity, all MS treatment strategies must be monitored to gather more safety data.

Based on the way they affect disease-causing cells, currently available therapies for MS can be divided into: (1) immunomodulators (interferon beta [IFN- $\beta$ ], glatiramer acetate [GA], dimethyl fumarate $[\mathrm{DMF}]$, teriflunomide [also a mild cell-depleting agent], daclizumab); (2) anti-trafficking agents (natalizumab, fingolimod); and (3) immune cell-depleting agents (mitoxantrone, cyclophosphamide, cladribine, ocrelizumab, alemtuzumab) (Table 2). ${ }^{10-25}$

The mechanisms of action of different agents may also contribute to the potential risk of specific toxicities. ${ }^{26,27}$ In the context of sequencing, some mechanisms of action might be considered complementary whereas others might indicate increased risk. For example, the use of natalizumab confers a greater risk of progressive multifocal leukoencephalopathy (PML), ${ }^{28}$ so possibly using it after another drug that has PML as a potential side effect such as DMF may confer additive PML risk. Contrast that with the use of teriflunomide, both an immunomodulator and mild celldepleting agent, together with IFN- $\beta$, a combination shown to be 
Table 1: Clinical and radiological factors suggestive of aggressive multiple sclerosis (MS) ${ }^{8,9}$

\begin{tabular}{l}
\hline Clinical features \\
\hline Demographics \\
Male sex \\
Older age ( $>40$ years) at onset \\
African American \\
African-Latin American \\
\hline Relapse severity \\
$\geq 1$-point change on EDSS, $\geq 2$-points change on any individual functional \\
$\quad$ system, or $\geq 1$-point change on any two functional systems \\
$\quad$ Steroid requirement \\
$\quad$ Hospitalization \\
\hline Type of attack \\
Multifocal \\
Partial or incomplete recovery \\
Attack affects motor, cerebellar, sphincteric, or cognitive functions \\
\hline Relapse frequency \\
Frequent relapses in the first 2-5 years \\
Short inter-attack interval \\
\hline Disease course \\
Rapid accrual of disability, e.g., EDSS score of 3.0 within 5 years, with \\
superimposed relapses \\
\hline MRI features \\
\hline At onset \\
High T2 lesion burden \\
More than two gadolinium-enhancing lesions \\
Presence of T1 lesions ('black holes') \\
Early discernable atrophy \\
Infratentorial lesions \\
\hline At follow-up \\
Presence of new T2 lesions \\
One or more new gadolinium-enhancing lesions \\
\hline
\end{tabular}

EDSS $=$ Expanded Disability Status Scale.

Adapted with permission from Rush et al. ${ }^{9}$ Copyright $^{\circledR} 2015$ MacMillan Publishers Limited.

both safe and synergistic. ${ }^{29}$ However, if the mechanism of action of an agent like GA is to produce regulatory cells that need to reach the CNS in order to work, then concomitant use of an antitrafficking drug might counteract that ability. ${ }^{30-32}$ On the other hand, based on their unique mechanisms of action, one could speculate that fingolimod followed by GA might be an "ideal sequence." Fingolimod might act first to round up all diseasecausing cells and sequester them in lymph nodes, ${ }^{33,34}$ where GA has its greatest action and shifts $\mathrm{T}$ cells from a mostly proinflammatory $\mathrm{T}$ helper (Th) 1 pattern of cytokine secretion to a mostly anti-inflammatory Th2 pattern. ${ }^{35}$

\section{Induction Therapies: Cell-Depleting Agents and their Impact on Sequential Therapeutic Approaches}

Induction therapy refers to the use of powerful cell-depleting therapy capable of eliminating disease-causing autoimmune cells up front in patients presenting with early active aggressive disease ( $10 \%$ of MS patients) ${ }^{36}$ Evidence from experimental models of MS and other immune-mediated diseases suggests that this type of approach might "reset" the immune system to prevent epitope spreading and control inflammatory disease activity more effectively than immunomodulation, thus preventing early structural damage, controlling disease progression, and preserving brain function. ${ }^{37}$ However, the duration of the induction treatment is often limited by specific toxicity and by cumulative doses. ${ }^{38}$ Serious side effects related to potent immunosuppressants such as mitoxantrone and cyclophosphamide are dose related, which is often a limiting factor. ${ }^{38}$ In the case of mitoxantrone, the risk of cardiotoxicity appears proportional to the total lifetime cumulative dose and it is increased in patients with a history of cardiac disease. In addition to cardiotoxicity, blood malignancies have been associated with mitoxantrone. Consequently, a complete blood count is recommended before each dose and each year after mitoxantrone treatment. Due to these serious safety concerns, lifetime cumulative doses of mitoxantrone should not exceed $140 \mathrm{mg} / \mathrm{m}^{2}$. Mitoxantrone exerts its therapeutic effect in MS through the inhibition of proliferation of $\mathrm{B}$ and $\mathrm{T}$ lymphocytes and macrophages. ${ }^{38}$ In addition, several other immunosuppressive effects have been described, such as decreased secretion of IFN- $\beta$, tumor necrosis factor- $\alpha$, and interleukin (IL)-2. ${ }^{38} \mathrm{~A}$ full course of mitoxantrone treatment can stabilize patients with aggressive MS for 5 years or more ${ }^{39}$ However, due to its long-term safety concern, lifetime exposure to mitoxantrone is limited. ${ }^{40}$ If maximal lifetime doses are reached, patients may require maintenance therapy with a DMT. It has been suggested that a short course of mitoxantrone followed by a first-generation immunomodulator (GA or IFN) after clinical stabilization of the disease may be an appropriate treatment strategy. ${ }^{39-41}$ However, due to potential toxicity and the emergence of other options mitoxantrone is now rarely used.

Alemtuzumab, a humanized monoclonal antibody that reduces circulating cluster of differentiation (CD) 52-positive cells, is another reasonable induction strategy. ${ }^{42}$ It can be used for a set number of courses and re-treatment is needed only in the context of return of disease activity. ${ }^{43}$ With alemtuzumab, CD52 cell depletion is sustained for up to 1 year, followed by lymphocyte repopulation and homeostatic resetting of the immune system. The biggest concern with this agent is the emergence of new autoimmune disorders, which occur in approximately one-third of patients and can develop several years after the last dose. ${ }^{44}$ Although the reason for this is unknown, it is speculated that it takes time for regulatory cells to return to normal. ${ }^{45}$ Most autoimmune events with alemtuzumab are thyroid related and are generally mild or moderate and manageable with timely detection and treatment. ${ }^{46}$ Unlike other agents with maximal lifetime exposure limits, alemtuzumab can be used beyond 2 years, as a 3-day annual treatment, in case of return of disease activity. A recent study demonstrated that alemtuzumab can also be used in patients previously treated with mitoxantrone. ${ }^{47}$

Other approaches with high efficacy and more selective lymphocyte depletion include agents such as cyclophosphamide. Cyclophosphamide is an alkylating agent that binds to deoxyribonucleic acid, interfering with mitosis and the cell cycle. ${ }^{48,49}$ Although extensive experience with cyclophosphamide in MS patients has been accumulated over the past 40 years, conclusive efficacy data are lacking. ${ }^{50}$ Yet, because of the differential risk for leukemia with mitoxantrone, cyclophosphamide may be preferred to mitoxantrone as induction therapy in rapidly progressing patients. ${ }^{51}$ Cyclophosphamide should also be considered in the event that approved first- and second-line drugs fail or when fingolimod, natalizumab, or mitoxantrone are contraindicated. ${ }^{52}$ It is important to remember, however, that previous use of 


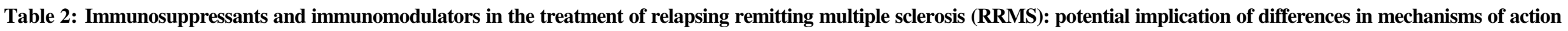

\begin{tabular}{|c|c|c|c|c|c|c|c|c|}
\hline Agent (brand name) & $\begin{array}{l}\text { Target/mechanism } \\
\text { of action }\end{array}$ & $\begin{array}{l}\text { Dose/frequency of } \\
\text { administration }\end{array}$ & Study (phase; control) & $\begin{array}{c}\text { Relapses/disease } \\
\text { progression (RRR) }\end{array}$ & MRI outcomes & Main AEs & $\begin{array}{l}\text { Most commonly } \\
\text { used line of therapy }\end{array}$ & Sequencing considerations \\
\hline \multicolumn{9}{|l|}{ Immunosuppressants } \\
\hline $\begin{array}{l}\text { Alemtuzumab } \\
\text { (Lemtrada) sc }\end{array}$ & $\begin{array}{l}\text { CD52 Recombinant } \\
\text { humanized } \\
\text { antibody }\end{array}$ & $12 \mathrm{mg}$ annual course & $\begin{array}{l}\text { CARE-MS II (Phase III } \\
\text { vs. sc IFN- } \beta \text {-1a) }{ }^{10}\end{array}$ & $\begin{array}{l}\text { ARR } 0.26 \text { vs. } 0.52 \\
\text { with IFN- } \beta-1 \mathrm{a} \\
\text { RRR } 42 \%\end{array}$ & $\begin{array}{l}\text { Reduction in new } \\
\text { T2 MRI } \\
\text { lesions: } 32 \% \\
\text { fewer patients } \\
\text { Reduction in } \\
\text { Gd + MRI } \\
\text { lesions: } 61 \% \\
\text { fewer patients }\end{array}$ & $\begin{array}{l}\text { Infusion reactions, } \\
\text { cytopenia, } \\
\text { secondary } \\
\text { autoimmunity, } \\
\text { infections }\end{array}$ & $\begin{array}{l}\text { Induction; second or } \\
\text { third line }\end{array}$ & $\begin{array}{l}\text { The biggest concern is the } \\
\text { emergence of new autoimmune } \\
\text { disorders } \\
\text { Can be used beyond } 2 \text { years, as a } \\
\text { 3-day annual treatment, in case } \\
\text { of return of disease activity } \\
\text { A recent study demonstrated that } \\
\text { alemtuzumab can also be used } \\
\text { in patients previously treated } \\
\text { with mitoxantrone } 77 \\
\text { When switching from fingolimod } \\
\text { to alemtuzumab, a minimum 4- } \\
\text { week washout period is advised } \\
\text { When switching from natalizumab } \\
\text { to alemtuzumab a bridging } \\
\text { strategy with an alternative } \\
\text { DMT may be used to prevent } \\
\text { reactivation of the disease }\end{array}$ \\
\hline $\begin{array}{r}\text { Cladribine } \\
\text { (Mavenclad) }\end{array}$ & $\begin{array}{l}\text { A synthetic analogue } \\
\text { of deoxyadenosine } \\
\text { that preferentially } \\
\text { reduces circulating } \\
\text { T and B } \\
\text { lymphocytes }\end{array}$ & $\begin{array}{l}\text { CLARITY trial: } \\
\text { tablets } 3.5 \mathrm{mg} / \mathrm{kg} \text { or } \\
5.25 \mathrm{mg} / \mathrm{kg}\end{array}$ & $\begin{array}{l}\text { CLARITY (Phase III vs. } \\
\text { placebo) }^{11}\end{array}$ & $\begin{array}{l}\text { ARR } 0.15 \text { vs. } 0.33 \\
\text { with placebo } \\
\text { RRR } 31 \%\end{array}$ & $\begin{array}{l}\text { Reduction in new } \\
\text { T2 MRI } \\
\text { lesions:75\% } \\
\text { Reduction in } \\
\text { Gd + MRI } \\
\text { lesions: } 87 \% \\
\end{array}$ & $\begin{array}{l}\text { Lymphocytopenia, } \\
\text { herpes zoster; } \\
\text { isolated cases of } \\
\text { malignancy were } \\
\text { reported }\end{array}$ & $\begin{array}{l}\text { Induction; second or } \\
\text { third }\end{array}$ & $\begin{array}{l}\text { There are some concerns about the } \\
\text { durability of therapy but re- } \\
\text { treatment after 1-2 years is } \\
\text { possible } \\
\text { Risk of malignancy is potential } \\
\text { concern }\end{array}$ \\
\hline $\begin{array}{l}\text { Cyclophosphamide } \\
\text { iv }\end{array}$ & $\begin{array}{l}\text { An alkylating agent } \\
\text { that binds to DNA, } \\
\text { interfering with } \\
\text { mitosis and the cell } \\
\text { cycle }\end{array}$ & $700 \mathrm{mg} / \mathrm{m}^{2}$ monthly & $\begin{array}{l}\text { Northeast Cooperative } \\
\text { MS Treatment Group } \\
\text { trial (iv } \\
\text { cyclophosphamide } \\
\text { induction with or } \\
\text { without outpatient iv } \\
\text { cyclophosphamide } \\
\text { boosters }(700 \mathrm{mg} / \\
\text { m }^{2} \text { every other month } \\
\text { for } 2 \text { years) } \\
\text { The Canadian } \\
\text { Cooperative Multiple } \\
\text { Sclerosis Study Group } \\
\text { (prospective, double- } \\
\text { blind, placebo- } \\
\text { controlled, } \\
\text { randomized trial) } \\
13\end{array}$ & $\begin{array}{l}\text { TTTF after } 1 \text { year } \\
\text { was significantly } \\
\text { prolonged in the } \\
\text { booster vs. the } \\
\text { non-booster } \\
\text { group }(p=0.03) \\
\text { No statistically } \\
\text { significant effect } \\
\text { on disability } \\
\text { progression at } 2 \\
\text { and } 3 \text { years }\end{array}$ & Not reported & $\begin{array}{l}\text { Nausea, vomiting; } \\
\text { amenorrhea, } \\
\text { infertility; alopecia }\end{array}$ & $\begin{array}{l}\text { Induction; second or } \\
\text { third }\end{array}$ & $\begin{array}{l}\text { Myelotoxicity; hepatotoxicity; } \\
\text { infections; hemorrhagic } \\
\text { cystitis; bladder cancer }\end{array}$ \\
\hline $\begin{array}{l}\text { Mitoxantrone } \\
\text { (Novantrone) sc }\end{array}$ & $\begin{array}{l}\text { Intercalates with } \\
\text { DNA; inhibits } \\
\text { topoisomerase II }\end{array}$ & $\begin{array}{l}12 \mathrm{mg} / \mathrm{m}^{2} \text { every } \\
3 \text { months until a } \\
\text { maximum } \\
\text { cumulative dose of } \\
140 \mathrm{mg} / \mathrm{m}^{2} \text { is } \\
\text { reached }\end{array}$ & $\begin{array}{l}\text { Randomised trial (IFN- } \beta \text { - } \\
1 \mathrm{~b})^{14}\end{array}$ & $\begin{array}{l}\text { ARR } 0.44 \text { vs. } 1.15 \\
\text { for IFN- } \beta \text {-1a } \\
\text { RRR } 65 \%\end{array}$ & $\begin{array}{c}\text { Patients without } \\
\text { Gd-enhancing } \\
\text { lesions at } 3 \\
\text { years; } 75 \%\end{array}$ & $\begin{array}{l}\text { URTI, leucopenia, } \\
\text { nausea }\end{array}$ & $\begin{array}{l}\text { Induction; second or } \\
\text { third }\end{array}$ & $\begin{array}{l}\text { Myelotoxicity; infections; } \\
\text { cardiotoxicity; acute leukemia } \\
\text { The risk of cardiotoxicity appears } \\
\text { proportional to the total lifetime } \\
\text { cumulative dose and it is } \\
\text { increased in patients with a } \\
\text { history of cardiac disease } \\
\text { Lifetime cumulative doses of } \\
\text { mitoxantrone should not exceed } \\
140 \mathrm{mg} / \mathrm{m}^{2}\end{array}$ \\
\hline
\end{tabular}




\begin{tabular}{|c|c|c|c|c|c|c|c|c|}
\hline $\begin{array}{l}\text { Ocrelizumab } \\
\text { (Ocrelizumab) iv }\end{array}$ & $\begin{array}{l}\text { CD20 Recombinant } \\
\text { humanized } \\
\text { antibody }\end{array}$ & $\begin{array}{l}\text { Not approved by } \\
\text { Health Canada for } \\
\text { MS }\end{array}$ & $\begin{array}{l}\text { OPERA I and OPERA II } \\
\text { (Phase III vs. IFN- } \beta- \\
\text { 1a) })^{15}\end{array}$ & $\begin{array}{l}\text { ARR } 0.16 \text { vs. } 0.29 \\
\text { with IFN- } \beta-1 \mathrm{a} \\
\text { RRR } 40 \%\end{array}$ & $\begin{array}{l}\text { Reduction in } \\
\text { Gd + MRI } \\
\text { lesions: 95\% } \\
\text { Reduction in new } \\
\text { T2 MRI } \\
\text { lesions: } 80 \%\end{array}$ & $\begin{array}{l}\text { infusion-related } \\
\text { reaction, } \\
\text { nasopharyngitis, } \\
\text { URTI, headache, } \\
\text { UTI, malignancy** }\end{array}$ & $\begin{array}{l}\text { Induction; second or } \\
\text { third line }\end{array}$ & $\begin{array}{l}\text { Potential increase in risk of cancer } \\
\text { (to be confirmed) }\end{array}$ \\
\hline \multicolumn{9}{|c|}{ First-generation injectable immunomodulators } \\
\hline $\begin{array}{l}\text { Glatiramer acetate } \\
\text { (Copaxone) sc }\end{array}$ & $\begin{array}{l}\text { Amino acid } \\
\text { copolymer, shifts } \\
\text { innate and adaptive } \\
\text { immune responses } \\
\text { toward anti- } \\
\text { inflammatory } \\
\text { pathway }\end{array}$ & $\begin{array}{l}20 \mathrm{mg} \text { daily or } 40 \mathrm{mg} \\
3 \times / \text { week }\end{array}$ & $\begin{array}{l}\text { Copolymer 1 MS Study } \\
\text { Group (Phase III } \\
\text { placebo) })^{16}\end{array}$ & $\begin{array}{l}\text { ARR } 0.59 \text { vs. } 0.84 \\
\text { with placebo } \\
\text { RRR } 12 \%\end{array}$ & $\begin{array}{l}\text { Reduction in new } \\
\text { T2 and Gd }+ \\
\text { MRI activity: } \\
30 \%\end{array}$ & $\begin{array}{l}\text { Injection-site } \\
\text { reactions; post- } \\
\text { injection reaction } \\
\text { (chest pain, } \\
\text { flushing and } \\
\text { dyspnea) }\end{array}$ & First line & $\begin{array}{l}\text { Cutaneous lipoatrophy, } \\
\text { anaphylaxis (rare) }\end{array}$ \\
\hline $\begin{array}{l}\text { IFN- } \beta-1 \mathrm{~b} \text { (Extavia) } \\
\text { sc }\end{array}$ & $\begin{array}{l}\text { Modulates expression } \\
\text { of anti-and pro- } \\
\text { inflammatory } \\
\text { cytokines; reduces } \\
\text { trafficking of } \\
\text { inflammatory } \\
\text { cells across blood- } \\
\text { brain barrier }\end{array}$ & $\begin{array}{l}250 \mu \mathrm{g} \text { every other } \\
\text { day }\end{array}$ & $\begin{array}{l}\text { The IFNB MS Study } \\
\text { Group }^{17}\end{array}$ & $\begin{array}{l}\text { ARR } 0.43 \\
\text { RRR } 29 \%\end{array}$ & $\begin{array}{l}\text { Reduction in new } \\
\text { T2 and Gd }+ \\
\text { MRI activity: } \\
83 \%\end{array}$ & \multirow{4}{*}{$\begin{array}{l}\text { The most common } \\
\text { side effects of IFN- } \\
\beta \text { include injection- } \\
\text { site reactions } \\
\text { (redness, pain, } \\
\text { pruritus, swelling, } \\
\text { lump) and flulike } \\
\text { symptoms (low- } \\
\text { grade fever, chills, } \\
\text { myalgia, arthralgia, } \\
\text { fatigue) }\end{array}$} & \multirow{4}{*}{ First line } & $\begin{array}{l}\text { Leukopenia, liver or thyroid } \\
\text { abnormalities, depression }\end{array}$ \\
\hline $\begin{array}{l}\text { IFN- } \beta-1 \mathrm{a} \\
\text { (Avonex) im }\end{array}$ & & $30 \mu \mathrm{g}$ weekly & $\begin{array}{l}\text { MSCRG (Phase III } \\
\text { placebo) }\end{array}$ & $\begin{array}{l}\text { ARR } 0.29 \\
\text { RRR } 37 \%\end{array}$ & $\begin{array}{l}\text { Reduction in new } \\
\text { T2 and Gd }+ \\
\text { MRI activity: } \\
52 \%\end{array}$ & & & \\
\hline $\begin{array}{l}\text { IFN- } \beta \text {-1a (Rebif) } \\
\text { sc }\end{array}$ & & $22 / 44 \mu \mathrm{g} 3 \times /$ week & $\begin{array}{l}\text { PRISM (Phase III } \\
\text { placebo) }^{19}\end{array}$ & $\begin{array}{l}\text { ARR } 0.37 / 0.42 \\
\text { RRR } 30 \%\end{array}$ & $\begin{array}{l}\text { Reduction in new } \\
\text { T2 and Gd }+ \\
\text { MRI activity: } \\
78 \%\end{array}$ & & & \\
\hline $\begin{array}{l}\text { Pegylated IFN- } \beta \text { - } \\
\text { 1a (Plegridy) sc }\end{array}$ & & $125 \mu \mathrm{g}$ every 2 weeks & $\begin{array}{l}\text { ADVANCE (Phase III } \\
\text { placebo) }^{20}\end{array}$ & $\begin{array}{l}\text { ARR } 0.18 \text { vs. } 0.49 \\
\text { with placebo } \\
\text { RRR } 38 \%\end{array}$ & $\begin{array}{l}\text { New or newly } \\
\text { enlarging T2 } \\
\text { hyperintense } \\
\text { lesions: mean } \\
3.6 \text { vs. } 10.9 \\
\text { placebo }\end{array}$ & & & \\
\hline \multicolumn{9}{|c|}{ Oral immunomodulators } \\
\hline $\begin{array}{l}\text { Dimethyl } \\
\text { Fumarate } \\
\text { (Tecfidera) oral }\end{array}$ & $\begin{array}{l}\text { Nuclear-related } \\
\text { factor-2/inhibits T } \\
\text { cell antigen } \\
\text { presentation; shifts } \\
\text { T cells toward an } \\
\text { anti-inflammatory } \\
\text { cytokine profile; } \\
\text { promotes } \\
\text { antioxidant } \\
\text { responses } \\
\end{array}$ & $240 \mathrm{mg}$ twice a day & $\begin{array}{l}\text { DEFINE (Phase III } \\
\text { placebo) }\end{array}$ & $\begin{array}{l}\text { ARR } 0.17 \text { vs. } 0.36 \\
\text { with placebo } \\
\text { RRR } 38 \%\end{array}$ & $\begin{array}{l}\text { Reduction in new } \\
\text { T2 MRI } \\
\text { lesions: 85\% } \\
\text { Reduction in } \\
\text { Gd + MRI } \\
\text { lesions: 90\% }\end{array}$ & $\begin{array}{l}\text { GI symptoms, } \\
\text { flushing, LFT } \uparrow \\
\text { Lymphopenia, UTI }\end{array}$ & First line & $\begin{array}{l}\text { Lymphopenia; progressive } \\
\text { multifocal } \\
\text { leukoencephalopathy }\end{array}$ \\
\hline $\begin{array}{l}\text { Fingolimod } \\
\text { (Gilenya) oral }\end{array}$ & $\begin{array}{l}\text { Sphingosine 1- } \\
\text { phosphate receptor/ } \\
\text { leads to receptor } \\
\text { downregulation in } \\
\text { lymph nodes, } \\
\text { preventing egress } \\
\text { of certain } \\
\text { populations of } \\
\text { lymphocytes in the } \\
\text { circulation }\end{array}$ & $0.5 \mathrm{mg} /$ daily & $\begin{array}{l}\text { TRANSFORMS (Phase } \\
\text { III; i.m. IFN- } \beta \text {-1a) })^{23}\end{array}$ & $\begin{array}{l}\text { ARR } 0.18 \text { vs. } 0.33 \\
\text { with IFN- } \beta-1 \mathrm{a} \\
\text { RRR } 30 \%\end{array}$ & $\begin{array}{l}\text { Reduction in new } \\
\text { T2 MRI } \\
\text { lesions: } 74 \% \\
\text { Reduction in } \\
\text { Gd + MRI } \\
\text { lesions: } 82 \%\end{array}$ & $\begin{array}{l}\text { Bradycardia, AVB, } \\
\text { macular edema, } \\
\text { infections, BP } \uparrow \\
\text { lymphopenia, } \\
\text { LFT } \uparrow\end{array}$ & Second line & $\begin{array}{l}\text { Risk of lymphopenia; viral } \\
\text { infections; cardiac effects; liver } \\
\text { enzyme elevations, macular } \\
\text { edema and isolated cases of } \\
\text { PML } \\
\text { When switching from fingolimod } \\
\text { to alemtuzumab, a minimum } \\
\text { 4-week washout period is } \\
\text { advised }\end{array}$ \\
\hline
\end{tabular}




\begin{tabular}{|c|c|c|c|c|c|c|c|c|}
\hline Agent (brand name) & $\begin{array}{l}\text { Target/mechanism } \\
\text { of action }\end{array}$ & $\begin{array}{l}\text { Dose/frequency of } \\
\text { administration }\end{array}$ & Study (phase; control) & $\begin{array}{c}\text { Relapses/disease } \\
\text { progression (RRR) }\end{array}$ & MRI outcomes & Main AEs & $\begin{array}{c}\text { Most commonly } \\
\text { used line of therapy }\end{array}$ & Sequencing considerations \\
\hline $\begin{array}{l}\text { Teriflunomide } \\
\text { (Aubagio) oral }\end{array}$ & $\begin{array}{l}\text { Dihydroorotate } \\
\text { dehydrogenase } \\
\text { (DHODH)/ } \\
\text { DHODH is } \\
\text { relevant for de novo } \\
\text { synthesis of } \\
\text { pyrimidine; } \\
\text { cytostatic effect on } \\
\text { proliferating B and } \\
\text { T cells }\end{array}$ & $14 \mathrm{mg}$ daily & $\begin{array}{l}\text { TEMSO (Phase III } \\
\text { placebo) }\end{array}$ & $\begin{array}{l}\text { AAR } 0.37 \text { vs. } 0.54 \\
\text { with placebo } \\
\text { RRR } 30 \%\end{array}$ & $\begin{array}{l}\text { Reduction in new } \\
\text { T2 MRI } \\
\text { lesions: } 67 \% \\
\text { Reduction in } \\
\text { Gd + MRI } \\
\text { lesions: } 80 \%\end{array}$ & $\begin{array}{l}\text { GI symptoms, } \\
\text { alopecia, BP } \uparrow, \\
\text { LFT } \uparrow, \text { PN }\end{array}$ & First line & $\begin{array}{l}\text { Myelotoxicity; hepatotoxicity; } \\
\text { infections; peripheral } \\
\text { neuropathy; pancreatic fibrosis; } \\
\text { teratogenicity (requires } \\
\text { accelerated elimination } \\
\text { procedure) }\end{array}$ \\
\hline \multicolumn{9}{|c|}{$\begin{array}{l}\text { Injectable immunomodulators } \\
\end{array}$} \\
\hline $\begin{array}{l}\text { Daclizumab } \\
\text { (Zinbryta) sc* }\end{array}$ & $\mathrm{CD} 25$ & $150 \mathrm{mg}$ every 4 weeks & $\begin{array}{l}\text { DECIDE (Phase III vs. im } \\
\text { IFN- } \beta \text {-1a) }\end{array}$ & $\begin{array}{l}\text { ARR } 0.22 \text { vs. } 0.39 \\
\text { with im IFN- } \beta \text {-1a } \\
\text { RRR 25\% }\end{array}$ & $\begin{array}{l}\text { Reduction in new } \\
\text { T2 MRI } \\
\text { lesions: } 54 \% \\
\text { Reduction in } \\
\text { Gd+ MRI } \\
\text { lesions: } 65 \% \\
\end{array}$ & $\begin{array}{l}\text { Infections, cutaneous } \\
\text { events, LFT } \uparrow\end{array}$ & Second or third line & $\begin{array}{l}\text { Recommended as } 2 \text { nd or 3rd line } \\
\text { of therapy }\end{array}$ \\
\hline $\begin{array}{l}\text { Natalizumab } \\
\text { (Tysabri) iv }\end{array}$ & $\begin{array}{l}\text { Very late antigen-4 } \\
\text { Blocks } \\
\text { transmigration of } \\
\mathrm{T} \text { cells into the } \\
\text { CNS }\end{array}$ & $\begin{array}{l}300 \mathrm{mg} \text { iv every } \\
4 \text { weeks }\end{array}$ & $\begin{array}{l}\text { AFFIRM (Phase III; } \\
\text { placebo) }\end{array}$ & $\begin{array}{l}\text { ARR } 0.23 \text { vs. } 0.73 \\
\text { with placebo } \\
\text { RRR } 42 \%\end{array}$ & $\begin{array}{l}\text { Reduction in new } \\
\text { T2 MRI } \\
\text { lesions: } 83 \% \\
\text { Reduction in } \\
\text { Gd+ MRI } \\
\text { lesions: } 90 \%\end{array}$ & $\begin{array}{l}\text { Infections (PML, } \\
\text { Herpes), infusion } \\
\text { reactions, } \\
\text { hepatotoxicity }\end{array}$ & Second line & $\begin{array}{l}\text { Rebound and return of activity } \\
\text { after treatment interruption } \\
\text { Risk of PML } \\
\text { Duration of washout period when } \\
\text { switching to another treatment } \\
\text { is of a concern- - assess risk of } \\
\text { rebound vs. risk of PML } \\
\text { When switching from } \\
\text { natalizumab to alemtuzumab a } \\
\text { bridging strategy with an } \\
\text { alternative DMT may be used to } \\
\text { prevent reactivation of the } \\
\text { disease }\end{array}$ \\
\hline
\end{tabular}

*Daclizumab was voluntarily removed from the market March 2, 2018 due to safety concerns. ${ }^{102} * *$ The true risk of malignancy, particularly breast cancer, requires further data. ARR $=$ annualized relapse rate; BP $=$ blood pressure; $\mathrm{CD}=$ cluster of differentiation; $\mathrm{DMF}=$ dimethyl fumarate; $\mathrm{DMT}=$ disease-modifying therapy; $\mathrm{Gd}=$ gadolinium; $\mathrm{GI}=$ gastrointestinal; im = intramuscular; $\mathrm{INF}=$ interferon beta; iv = intravenous; $\mathrm{LFT}=$ liver function tests; PML = progressive multifocal leukoencephalopathy; PN = peripheral neuropathy; RRR = relative risk reduction; $s c=$ subcutaneous; $T T T F=$ time to treatment failure; $\mathrm{URTI}=$ upper respiratory tract infections; UTI = urinary tract infection. 
non-selective immunosuppressive drugs increases the risk of PML in natalizumab-treated patients ${ }^{28}$ and may also confer risk of PML with other agents such as DMF or fingolimod. ${ }^{53-55}$

Cladribine, a synthetic purine nucleoside and antimetabolite that acts as an antineoplastic agent with immunosuppressive effects, might be used in a similar manner to alemtuzumab. ${ }^{56,57}$ Animal data suggest that the drug is capable of crossing the blood-brain barrier, ${ }^{58}$ and it was found to be beneficial for patients with RMS. ${ }^{13,59,60}$ Cladribine is an option for patients with aggressive $\mathrm{MS},{ }^{61}$ although the cladribine tablet formulation was previously rejected in 2011 because of malignancy concerns. ${ }^{62}$ A recent meta-analysis of Phase III trials of licensed DMTs for MS and the CLARITY trial did not support an increased cancer risk from cladribine in the doses used in CLARITY. ${ }^{63}$ The latest data from the extension phase of CLARITY showed that two to four short oral courses (one dose per day for 4-5 days) of cladribine in year 1 and two short courses in year 2 were associated with durable efficacy. ${ }^{64}$ There are some data concerning the durability of therapy but re-treatment after 1-2 years is possible. Cladribine tablets have now been approved in Europe and Canada for $\mathrm{RMS}^{65,66}$

\section{Escalation Therapies: Immunomodulators and their Impact on Sequential Therapeutic Approaches}

Due to the limitations of immunosuppressive/ablative therapies, disease-causing cells may not be completely eliminated in many cases, resulting in breakthrough disease. In some instances, re-treatment with another course of the same therapy may be possible (e.g. alemtuzumab, cladribine). Given the risk of disease return, an appropriate alternative is to consider long-term maintenance following induction therapy, generally with safer immunomodulatory agents, to extend the benefit obtained with aggressive treatment; but such an approach has not been subjected to any form of rigorous study to date. The concept of escalation and maintenance therapy represents a strategy that gives precedence to safety over efficacy and, if necessary, to sequentially advance in the treatment pyramid. ${ }^{67-69}$ In this approach, individuals start with first-line agents and are switched to second- or even third-line agents if they exhibit breakthrough disease that pushes them from low to high in terms of the risk for imminent disease progression. For the purpose of this paper, the definitions and categorization of MS medications as first-, second-, and thirdline drugs previously outlined in Freedman et $\mathrm{al}^{5}$ have been used. It should be noted that the designation of first, second, and thirdline agents is not evidence-based as all of the available treatments licensed for MS have been studied primarily as first-line agents. Escalation and maintenance therapy is appropriate for most patients with non-aggressive RMS, provided that they are closely monitored to detect suboptimal response or disease progression.

Sequential DMT monotherapy is currently the most common treatment strategy for RMS with injectables such as IFN- $\beta$ or GA, along with teriflunomide or DMF being the most frequently used first-line therapies. Injectable IFN- $\beta$ or GA as well as teriflunomide and cladribine have approved indications not only for patients with RMS but also for those with early MS, including patients with clinically isolated syndrome who are at high risk for the development of more active MS. ${ }^{8}$ Recent evidence indicates that early initiation of DMT is beneficial over the long term, resulting in significant reduction of long-term disability. $5,36,43,67-70$
Although the injectable mode of administration of IFN- $\beta$ or GA may be inconvenient for some patients, it is important to keep in mind the wealth of experience with these drugs in regard to dosing and toxicity management. Newer formulations have attempted to increase convenience with a pegylated version of IFN- $\beta$ used every 2 weeks ${ }^{71}$ and a new formulation of GA taken just thrice weekly. ${ }^{72}$ With DMF, for example, the management of severe flushing and/or gastrointestinal toxicities continues to be a problem and efforts continue to reduce these side effects. ${ }^{73}$ The DEFINE study suggested that half dose for 1 month (240 mg daily dose $)^{74}$ is more appropriate in regard to achieving desirable gastrointestinal tolerability than the extended titration $(120 \mathrm{mg}$ $3 \times$ /day $360 \mathrm{mg}$ daily dose). ${ }^{75}$ However, doses lower than $240 \mathrm{mg}$ daily are not as effective in reducing brain MRI activity. ${ }^{76}$

First-generation immunomodulators also have wellestablished short- and long-term safety profiles. Therefore, even if new oral first-line drugs such as teriflunomide ${ }^{77}$ and $\mathrm{DMF}^{78}$ may appear more convenient from the patient perspective and have a positive effect on treatment adherence and the patient's quality of life, ${ }^{79}$ it is important to keep in mind that there are still significant uncertainties regarding their long-term effects.

Several cases of PML have been reported with DMF, some of which were not related to previous use of immunosuppressants. ${ }^{53,54}$ In most, but not all cases, the patients had low lymphocyte counts (grade 2 or 3 lymphopenia). ${ }^{53,80}$ Lymphopenia is a frequent outcome of DMF therapy and in clinical practice lymphopenia appears to be more common than reported in clinical trials. A retrospective cohort study of 221 patients prescribed DMF at a single academic medical center suggested that the cumulative incidence of grade 3 lymphopenia exceeds $20 \%$ in adults older than 55 years; combined grade 2 and 3 lymphopenia developed in more than $40 \%$ of patients in this age group. ${ }^{81} \mathrm{~A}$ higher risk of lymphopenia was noted in patients switching to DMF from natalizumab therapy and in those with lower baseline lymphocyte counts. Fingolimod and natalizumab are involved in immune cell trafficking that impedes lymphocyte migration across the blood-brain barrier (natalizumab) and/or from exiting lymph nodes into the circulation (fingolimod), preventing CNS inflammation. $^{82}$ While these therapies may offer substantial efficacy as a consequence of their mechanism of action, their alteration of lymphocyte distribution may influence immune surveillance and increase the risk of infections and PML.

There have been very few "head-to-head" studies using DMTs. High-dose IFN- $\beta 1$ a given subcutaneously three times per week (tiw) has been proven superior to the once-weekly intramuscular IFN- $\beta 1$ a ${ }^{83}$ Fingolimod was shown to be superior to intramuscular once-weekly IFN- $\beta 1 \mathrm{a},{ }^{23}$ daclizumab is superior to once-weekly IFN- $\beta 1 \mathrm{a}^{25}$ and both alemtuzumab ${ }^{84}$ and ocrelizumab ${ }^{85}$ were proven superior to subcutaneous IFN- $\beta 1$ a tiw. Although natalizumab is believed to be more potent on clinical and MRI outcomes than first-line injectable immunomodulators, ${ }^{86}$ this has never been shown in properly controlled studies, but is substantiated only with large, "real world" observational data sets. ${ }^{87}$

With respect to escalation from either IFN- $\beta$ or GA to natalizumab, retrospective and observational studies have indicated that switching is associated with a significant reduction in clinical and radiological activity. ${ }^{88-90}$ A switch from IFN- $\beta$ to fingolimod has also been shown to produce significant reductions in clinical and radiological activity. ${ }^{91}$ However, no large head-to-head studies or evidence-based criteria exist to guide the choice between 
fingolimod and natalizumab. Thus, apart from the presence/ absence of anti-JCV antibodies (researched only in the context of natalizumab) the choice is empirical, although some small, observational, uncontrolled studies suggest that natalizumab may be superior to fingolimod in RMS patients not responding to first-line agents. ${ }^{92-95}$ According to the recent report from the MSBase registry, alemtuzumab and natalizumab seem to have similar effects on annualized relapse rates in RMS. While alemtuzumab was superior to fingolimod and IFN- $\beta$ in mitigating relapse activity, natalizumab was superior to alemtuzumab in enabling recovery from disability. Thus, according to the investigators, treatment decisions between alemtuzumab and natalizumab should be primarily governed by their safety profiles. ${ }^{96}$

Ocrelizumab is a humanized monoclonal antibody that selectively targets CD20. The superior efficacy of ocrelizumab over IFN- $\beta$ 1a was proven in two Phase III clinical trials OPERA 1 and OPERA 2 that included $\sim 800$ patients with RMS. ${ }^{14}$ However, four neoplasms (two breast cancers, one renal cancer, and one melanoma) occurred in patients treated with ocrelizumab $(0.5 \%)$ versus two occurrences in the IFN- $\beta 1$ a group $(0.2 \%)$. Five additional malignancies were also detected during the open-label extension phase. In the ORATORIO trial involving patients with primary progressive MS, 11 neoplasms were reported, four of which were breast cancer. ${ }^{97}$ Thus, long-term follow-up with larger numbers of patients will be necessary to assess these risks more fully. Similar to malignancies observed with cladribine, it is unknown whether the cancer risk is idiosyncratic or related to the duration of therapy. Ocrelizumab was recently approved by Health Canada for the treatment of adult patients with RMS, with active disease defined by clinical and imaging features. ${ }^{98}$

Daclizumab is a humanized IgG1 monoclonal antibody directed against CD25, the alpha subunit of the high-affinity IL-2 receptor. ${ }^{99}$ As demonstrated in the Phase III DECIDE trial, $25 \mathrm{mg}$ once-monthly subcutaneous daclizumab was superior to onceweekly intramuscular IFN- $\beta$-1a in reducing the clinical relapse rate and radiological measures of disease in patients with RMS. In addition, daclizumab has demonstrated efficacy in reducing disability progression and in improving health-related quality of life. Toxicity profile includes hepatic, infectious, and cutaneous events. Despite its availability, the place of daclizumab, functioning mainly as an immunomodulator in MS treatment remains to be fully determined. Based on available evidence, EMA advised against using daclizumab in patients with pre-existing hepatic disease or hepatic impairment and in patients with autoimmune diseases other than MS, and they urge caution when using the drug in combination with drugs that can damage the liver. ${ }^{100}$ In Canada, daclizumab was approved as second- or third-line option. ${ }^{101}$ However, as of March 2, 2018, Biogen and AbbVie voluntarily removed daclizumab from the market worldwide due to safety concerns voiced by the European Medicines Agency after 8 patients in Europe presented with encephalitis and/or menigoencephalitis. ${ }^{102}$

\section{Suggested Strategies to Decrease the Risk of PML with Natalizumab}

The increased risk of the development of PML with different DMTs, especially natalizumab, is well established. ${ }^{53}$ As of December 7, 2017, there have been 756 confirmed PML cases (753 MS, three Crohn's Disease). ${ }^{103}$ As of November 30, 2017 , $\sim 177,800$ patients received natalizumab, yielding an incidence of
4.22 in 1000 treated patients. The global overall incidence of PML in natalizumab-treated patients is 4.22 per 1000 patients $(95 \%$ confidence interval 3.93-4.54 per 1000 patients). ${ }^{103}$ The risk is particularly high in patients treated with natalizumab for longer than 12 months, those who had previous exposure to immunosuppressive therapies, and those with a high anti-JCV antibody index. ${ }^{103-105}$ With the availability of several other DMTs, it is now possible to reduce the risk of PML by switching JCV-seropositive patients treated with natalizumab to another agent. One caveat is that previous exposure to natalizumab may have prolonged effect

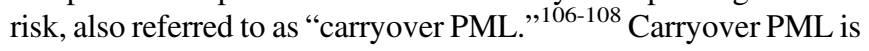
the result of the complex pathogenesis of PML, which develops over months to years. ${ }^{104}$ One strategy to reduce the risk of carryover PML is to washout natalizumab before starting another DMT, allowing immune reconstitution of the CNS. ${ }^{106}$ The obvious downside of this strategy is rebound effect and return of disease activity. ${ }^{108,109}$ To overcome this risk, several approaches have been tried. ${ }^{110-113}$ Yet, currently the only effective method to prevent rebound appears to be either fingolimod ${ }^{12}$ or teriflunomide ${ }^{113}$ without any washout period. It is important to be aware that the risk of PML after stopping natalizumab is unlikely to disappear completely.

As JCV reactivation in the CNS is not fully understood, clinical pharmacovigilance is warranted as there might be a risk from either current or previous therapy. Furthermore, it appears that, despite stratification algorithms and the available test for JCV serology, the incidence of PML in natalizumab-treated MS patients has continued to increase, likely because patients are kept on the drug too long. ${ }^{114,115}$ In their recent editorial, Mowry and McArthur ${ }^{15}$ suggest the development of Apps or online calculators for PML risk, as has been done for cardiovascular risk. Clinicians need to acknowledge that the incidence of PML remains high and not to rely on cutpoints, but rather appreciate that risk continues to accumulate with increased treatment duration. Given that PML may develop even after natalizumab discontinuation, it is possible that the longer a patient waits after becoming JCV antibody-positive before switching, the higher the risk of PML will become. ${ }^{115}$

\section{Course to Follow When Considering Treatment Modification \\ Factors to Consider When Moving to the Next Line of Therapy}

The excitement surrounding new effective DMTs is tempered by concerns about both known and unknown additional risks. Although in many instances the rationale after relapse is to try a DMT with a different mechanism of action, the impact of a previous therapy on potential toxicity profile needs to be considered. In addition, washout period and potential for rebound effect present additional challenges when moving to the next line of therapy. For example, as fingolimod traps lymphocytes in the lymph nodes, ${ }^{116}$ efficacy of subsequent agents that target circulating lymphocytes such as alemtuzumab ${ }^{117}$ may be compromised. Fingolimod has a pharmacologic half-life of 6-9 days and lymphocytes would be expected to normalize 2-4 weeks after discontinuation. ${ }^{118}$ Therefore, it is recommended to stop fingolimod for 4 weeks, checking peripheral lymphocyte counts to ensure that they are returning towards normal before giving the first course of alemtuzumab, in order to maximize its effect on 
circulating lymphocytes. ${ }^{107}$ From a safety standpoint, moving from natalizumab or fingolimod (and probably DMF) - agents that have proven in monotherapy to cause PML - to alemtuzumab requires additional consideration. Should latent PML (i.e. active copies of JCV) be present and a patient switched to alemtuzumab, the patient will be immunocompromised and the PML can be life threatening. Such patients should probably undergo a lumbar puncture, with measurement of CSF for JCV polymerase chain reaction, before starting alemtuzumab or any other potent immunosuppressant, as a precautionary measure.

\section{Managing pregnancy-related issues in patients with RMS}

The theoretical potential for teratogenicity is relevant for all DMT when considering the treatment of female patients of childbearing age, but the risk varies among agents. In general, patients should be advised to discontinue DMTs before conception although there are suggestions that IFN- $\beta^{119}$ and $\mathrm{GA}^{120}$ can be continued throughout pregnancy in patients with severe or highly active disease. Fingolimod should be discontinued 2-3 months before the cessation of contraception, ${ }^{121}$ and evidence regarding the discontinuation of natalizumab is not clear considering the high risk of disease recurrence even during pregnancy. ${ }^{122}$ Teriflunomide is associated with a theoretical risk of teratogenicity, despite little evidence for this in the treatment of $\mathrm{MS},{ }^{123}$ and the Food and Drug Administration regulation changed in regard to labeling all pharmaceuticals regarding the risk during pregnancy. ${ }^{124}$ Most of the warnings for teriflunomide derive from those tagged to the parent drug, leflunomide, used for the treatment of rheumatoid arthritis. ${ }^{125}$ Without going through an accelerated 11-day elimination procedure, ${ }^{125}$ teriflunomide is eliminated slowly from plasma and it can take up to 2 years to achieve systemic clearance at a level where teratogenicity is theoretically unlikely. Across nine Phase II/III clinical studies with teriflunomide a total of 71 pregnancies were reported. ${ }^{126}$ Upon learning of their pregnancies, patients were instructed to discontinue their study treatment and undergo an accelerated elimination procedure (cholestyramine or activated charcoal). In total, 44 of the 71 pregnancies were reported in patients exposed to teriflunomide; the remaining pregnancies occurred in patients treated with placebo, IFN- $\beta$, or blinded therapy. In the 17 live births, including 12 exposed to teriflunomide, no structural defects or functional deficits have been reported. The duration of fetal exposure was up to 11 weeks and newborns had birth weights between 2780 and $4150 \mathrm{~g}$. Thus far there is no signal for teratogenicity in newborns with prenatal teriflunomide exposure following accelerated elimination although more prospective data are needed with respect to pregnancy outcomes. The recent report on the outcomes of pregnancies occurring in the teriflunomide clinical program ( $n=69$ pregnancies) and in the post-marketing setting ( $n=171$ pregnancies) confirmed these observations. ${ }^{127}$

\section{Tests to Obtain Before Attempting Treatment Modification}

Detection of anti-JCV antibodies in serum or plasma using a two-step enzyme-linked immunosorbent assay has been proposed to stratify the risk of PML. Testing for JCV antibody status is recommended for all natalizumab candidates before treatment initiation as well as before starting a new therapy after having taken natalizumab, DMF, or fingolimod. Natalizumab is generally not recommended in patients who are JCV antibody-positive and have received prior immunosuppressants, such as mitoxantrone or cyclophosphamide; however, the risk of other agents such as cladribine, alemtuzumab, or ocrelizumab are unknown. ${ }^{115}$

Patients considered for fingolimod should be assessed for cardiovascular disease, diabetes, and liver dysfunction. As fingolimod can also increase low-density lipoprotein and total cholesterol, evaluation of serum lipids should be part of routine monitoring for patients taking fingolimod. ${ }^{128}$ As increased susceptibility to serious viral infections was noticed during the TRANSFORMS trial, ${ }^{23}$ patients considering fingolimod should probably be vaccinated against the varicella zoster virus and immunity confirmed before initiating therapy. ${ }^{128}$ Furthermore, due to the immunosuppressive mode of action of fingolimod, an increased awareness of infectious complications is required. ${ }^{129,130}$ Cases of cryptococcal infections, including cryptococcal meningitis, and systemic meningitis, have been reported in patients taking fingolimod. ${ }^{131,132}$

Although a recent study found no increased risk of early relapse (within the first 6 months) following switch of patients previously stable on injectable therapy to oral treatment, ${ }^{133}$ the longer-term ( $>6$ months) risk of relapse is unknown. The long-term adverse event profile of most oral agents has yet to be established compared with the injectable immunomodulators IFN- $\beta$ and GA.

\section{Washout Period}

Transitioning from one particular DMT to another can be complex, and a washout period may be required in certain circumstances. There is a paucity of data regarding the optimal washout period when switching from one agent to another. Furthermore, it is often unclear for which treatment transitions a washout period is required, how long it should last, or what long-term safety surveillance procedures should be implemented. Nevertheless, concomitant treatment within the washout period of the previous DMT is not advisable, owing to the potential risk of carry-over PML from previous treatment and additive effects on the immune system. Consequently, it is important to consider the half-life as well as the mechanism of action of the previous DMT when transitioning from one therapy to another.

In general, a washout period is not required when switching from first line injectable to any other treatment. As mentioned, an accelerated elimination protocol may be advisable when switching from teriflunomide to another agent due to the long half-life of the drug. ${ }^{125}$

When switching from fingolimod to alemtuzumab, a minimum 4-week washout period is advised. ${ }^{101,134,135}$ Recent reports of patients treated with fingolimod who experienced significant rebound of disease activity when switched to alemtuzumab indicate that one must wait for lymphocytes to desequester in order to get the most out of the first 5-day course of alemtuzumab. ${ }^{134,135}$ Because of the potential for PML in patients on fingolimod alone, it is imperative that PML be ruled out before initiating alemtuzumab for reasons outlined below. An "exit MRI" along with CSF for JCV PCR is strongly recommended.

The proposed mechanism of action of DMF (activation of the nuclear factor erythroid 2-related factor 2) would generally not foresee any issues with rapid transition to another therapy, ${ }^{134}$ although DMF has also been shown to have a lymphopenic effect in certain patient populations. ${ }^{136}$ Thus, similar to fingolimod, a washout period might be advisable when transitioning from DMF to 
alemtuzumab. ${ }^{137,138}$ For both drugs, however, the time period over which lymphocytes return to normal is variable and can take many months, during which time the patient is at risk of relapse. ${ }^{137}$ This is a significant challenge in sequencing from DMF. As DMF has also had cases of PML associated with it, an "exit MRI" and CSF for JCV PCR is recommended before initiating alemtuzumab (see below).

Teriflunomide is also associated with a reduction in lymphocytes and neutrophil counts. However, patients receiving teriflunomide have the opportunity to undergo an accelerated elimination procedure, potentially allowing the initiation of alemtuzumab relatively quickly after stopping teriflunomide.

As natalizumab does not reduce circulating lymphocyte counts, rather it blocks their entry to the CNS resulting in only mild lymphocytosis, ${ }^{137,138}$ there may be limited benefit in delaying initiating treatment with another DMT following natalizumab discontinuation. ${ }^{138}$ It has also been suggested that starting a new treatment immediately after stopping natalizumab (without washout period) may be more beneficial because the risk of developing PML is lower than the risk of a severe relapse. ${ }^{139,140}$

However, despite preferred outcomes in the absence of a prolonged washout period after natalizumab, it is important when switching to confirm JCV status and exclude any PML carryover in JCV-positive patients by MRI and by cerebrospinal fluid examination for JCV DNA, before treatment initiation. This is of particular relevance when patients are switched from natalizumab to alemtuzumab as the effects of alemtuzumab cannot be reversed in the short term, and, if carry-over PML develop following alemtuzumab treatment, it is unlikely that full immune cell repopulation can occur and that patients will be unable to clear the virus. Thus, when switching from natalizumab to alemtuzumab, either this should occur swiftly, as soon as an "exit MRI" and CSF study ruling out JCV

Table 3: Level of concern according to the criteria for relapse, Expanded Disability Status Scale (EDSS) progression, and MRI findings 5

\begin{tabular}{|c|c|c|c|}
\hline & \multicolumn{3}{|c|}{ Level of concern } \\
\hline Criteria & Low & Medium & High \\
\hline \multicolumn{4}{|l|}{ Relapse } \\
\hline Rate & 1 relapse in the second year of treatment & 1 relapse in the first year of treatment & $>1$ relapse in the first year of treatment \\
\hline Severity & $\begin{array}{l}\text { Mild } \\
\text { Steroids not required } \\
\text { Minimal effect on ADL } \\
1 \text { functional domain affected } \\
\text { No or mild motor/cerebellar involvement }\end{array}$ & $\begin{array}{l}\text { Moderate } \\
\text { Steroids required } \\
\text { Moderate effect on ADL } \\
>1 \text { functional domain affected } \\
\text { Moderate motor/cerebellar } \\
\quad \text { involvement }\end{array}$ & $\begin{array}{l}\text { Severe } \\
\text { Steroids/hospitalization required } \\
\text { Severe effect on ADL } \\
>1 \text { functional domain affected } \\
\text { Severe motor/cerebellar involvement }\end{array}$ \\
\hline Recovery (duration) & $\begin{array}{l}\text { Prompt recovery } \\
\text { No functional deficit }\end{array}$ & $\begin{array}{l}\text { Incomplete recovery at } 3 \text { months } \\
\text { Some functional impairment }\end{array}$ & $\begin{array}{l}\text { Incomplete recovery at } 6 \text { months } \\
\text { Functional impairment }\end{array}$ \\
\hline \multicolumn{4}{|l|}{ EDSS progression } \\
\hline \multicolumn{4}{|l|}{ EDSS score } \\
\hline$\leq 3.5$ & $\leq 1$ point & 2 points at 6 months* & $\begin{array}{l}>2 \text { points at } 6 \text { months* } \\
2 \text { points at } 12 \text { months* }\end{array}$ \\
\hline 4.0 to 5.0 & $<1$ point & 1 point at 6 months* & $\begin{array}{l}>1 \text { point at } 6 \text { months* } \\
1 \text { point at } 12 \text { months* }\end{array}$ \\
\hline$>5.5$ & & 0.5 point at 6 months* & $>0.5$ point at 6 months \\
\hline $\begin{array}{l}\text { Clinically documented } \\
\text { progression }\end{array}$ & $\begin{array}{l}\text { No motor } \\
\text { Minor sensory }\end{array}$ & $\begin{array}{l}\text { Some motor, cerebellar, or cognitive } \\
\text { Multiple EDSS domains affected }\end{array}$ & $\begin{array}{l}\text { Pronounced motor, cerebellar, or cognitive } \\
\text { Multiple EDSS domains affected }\end{array}$ \\
\hline $\mathrm{T} 25 \mathrm{FW}^{* *}$ & $<20 \%$ confirmed at 6 months & $\begin{array}{l}>20 \% \text { and }<100 \% \text { increase } \\
\text { confirmed at } 6 \text { months }\end{array}$ & $>100 \%$ increase confirmed at 6 months \\
\hline \multicolumn{4}{|l|}{ MRI findings } \\
\hline \multicolumn{4}{|l|}{ Activity on MRI* } \\
\hline $\begin{array}{l}\text { New Gd-enhancing lesions OR } \\
\text { Accumulation of new } \\
\text { T2 lesions per year }\end{array}$ & 1 lesion & 2 lesions & $>3$ lesions \\
\hline
\end{tabular}

$\mathrm{ADL}=$ activities of daily living

When considering a switch in therapy, whether it is a lateral switch between two agents in the same line of therapy (e.g., interferon beta [IFN- $\beta$ ] to glatiramer acetate $[\mathrm{GA}]$ ) or treatment escalation to a second-line agent, clinicians should first determine if suboptimal treatment response warrants a switch in treatment. This can be done by determining the level of concern according to the criteria for relapse, EDSS progression, and MRI.

The level of concern should be reassessed and determined at regular follow-up intervals, typically every 6 or 12 months. Routine follow-up MRI with gadolinium $(\mathrm{Gd})$ is recommended 6-12 months after initiating therapy for relapsing remitting multiple sclerosis (or in clinically isolated syndrome if therapy is not initiated). New T2 lesions that are also enhancing on the same scan are only counted once as unique active lesions. The presence of Gd-enhancing lesions is more reliable than new T2 lesion counts. New T2 lesion counts require high-quality comparable MRI scans and interpretation by highly-qualified individuals. *If EDSS progression alone is used to assess response to treatment, any change requires subsequent confirmation at 3-6 months.

**Timed 25-foot walk (T25FW) tested at baseline with aid, if required 
by PCR are performed, or a bridging strategy with an alternative DMT may be required in the interim to prevent reactivation of the disease.

Given that there was a PML case described with ocrelizumab as a carryover from natalizumab ${ }^{141}$ switching from natalizumab to ocrelizumab should be done the same way as alemtuzumab with the same precautionary CSF analysis and MRI.

When switching from natalizumab to fingolimod, a washout period of $>3$ months is associated with an increased risk of disease reactivation. ${ }^{142-144}$ The latest evidence suggests that no washout period is recommended. ${ }^{113}$ However, since both drugs carry a risk of PML, it would be important to perform an "exit MRI" and CSF for JCV PCR before initiating fingolimod as there have been many cases of "carry-over" PML from natalizumabtreated patients initiated on fingolimod. ${ }^{145,146}$

\section{Treatment Discontinuation}

Sometimes RMS patients receiving DMT may decide to interrupt their therapy due to various personal reasons (e.g. travel, pregnancy). These patients should continue to be periodically monitored both clinically and by MRI. Pregnancy planning requires DMT discontinuation (unless the benefit to the mother outweighs the risk to the fetus) with the appropriate timing according to the drug-specific pharmacokinetics. ${ }^{147}$ Discontinuation of antitrafficking agents presents significant concern for a rebound syndrome. ${ }^{148}$ Cases of fulminant relapse after stopping natalizumab, leading to death despite intensive care and immunosuppressive therapy, have been reported. ${ }^{108}$ Rebound effect and the development of tumefactive demyelinating lesions were also reported in patients who stopped fingolimod in order to conceive. ${ }^{149,150}$

Therefore, patients should be cautioned that some medications pose additional issues upon discontinuation. This is important especially in pregnancy planning as a bridging strategy to prevent rebound might be initiated before discontinuing anti-trafficking agents. If disease worsening is detected in patients who stopped their DMT, the decision to restart the treatment should be revisited.

\section{Combination Therapy}

Combination therapy, allowing for treatments with different mechanisms of action to accomplish better disease control, could be an effective strategy for MS. However, limited evidence, concerns regarding potential additive effects, increased risk of toxicity, and cost concerns are all obstacles to wider uptake of combination therapy in MS. According to Phase II data, some combinations are both highly effective and safe, at least in the short term. ${ }^{151,152}$ Combined teriflunomide and IFN- $\beta$ produce additive responses, especially on MRI. ${ }^{152}$ The combination of natalizumab and GA appeared safe and well tolerated during 6 months of therapy. ${ }^{152}$ Currently, cost is one of the main reasons prohibiting combination therapy, despite the fact that some combinations might well afford synergy due to their different mechanisms of action.

\section{Evaluating Treatment Response}

A full review of methodologies to evaluate treatment response to disease-modifying medication is beyond the scope of this paper. However, recommendations for the clinical assessment of relapses, which comprise relapse rate, severity, and recovery, have been outlined previously by Freedman et al (Table 3). ${ }^{5}$ Critical factors affecting the decision of changing the current DMT are listed in Table $4 .^{26}$ A new MRI with gadolinium is recommended 6-12 months after treatment initiation or switching to establish a new "reference" MRI for future comparison.,126 Typically another MRI is recommended within a year of the new "reference" scan for full evaluation of treatment response.

\section{Conclusion}

The availability of new treatment options for MS provides an opportunity for improving long-term clinical outcomes. However, it has also made patient management more complex. The suggestions regarding the sequencing of MS therapies outlined in this manuscript were developed to assist clinical neurologists in their management of RMS patients.

When switching the RMS patient from one therapy to another, it is essential to consider cumulative toxicities. At the same time risk of disease reactivation and rebound effect need to be taken into consideration should too much time pass between stopping one agent and starting the next. The patient should undergo full general and neurological examinations and laboratory measurements, as well as getting either an "exit MRI" (in the case of PML

Table 4: Factors affecting the decision to modify disease-modifying therapies (DMT) for multiple sclerosis ${ }^{26}$

\begin{tabular}{|c|c|}
\hline Factors suggesting a switch from a first-line DMT to another first line (lateral switch) & $\begin{array}{l}\text { Tolerability/safety issues } \\
\text { Suboptimal efficacy with suboptimal response but still a low risk for imminent } \\
\text { progression }\end{array}$ \\
\hline Factors suggesting a switch from a first-line to a second-line DMT (i.e. escalation) & $\begin{array}{l}\text { Anyone with a suboptimal response as defined by the Canadian } \mathrm{TOR}^{5} \text { to first-line DMT } \\
\text { who has a moderate-higher risk for progression (as opposed to low risk) } \\
\text { RRMS patients transitioning to the secondary progressive phase with evidence of relapses } \\
\text { or MRI activity (such patients can also be considered for induction therapy) }\end{array}$ \\
\hline $\begin{array}{l}\text { Factors suggesting a switch from a second-line DMT to a third-line or higher DMT } \\
\text { (i.e. these are the patients who moved to a higher risk for progression and the first- and } \\
\text { second-line DMTs would not be able to change the risk) }\end{array}$ & $\begin{array}{l}\text { RRMS patients continuing to experience relapses on a second-line therapy } \\
\text { Progressive forms of MS with relapses and/or active MRI despite treatment; such patients } \\
\text { can also be considered for induction therapy } \\
\text { Safety issues (e.g., patients on natalizumab at high risk of developing progressive } \\
\text { multifocal leukoencephalopathy) }\end{array}$ \\
\hline Factors suggesting a switch from a second-line to a first-line DMT & $\begin{array}{l}\text { Tolerability/safety issues should the patient maintain the second-line agent AND the } \\
\text { perception that the disease is under good control and the patient's risk for imminent } \\
\text { progression has been reduced }\end{array}$ \\
\hline
\end{tabular}

RRMS = relapsing remitting multiple sclerosis; TOR = Treatment Optimization Recommendations.

Adapted from: Gajofatto et al. ${ }^{94}$ 
causing agents) or a new "reference" MRI (done 3-6 months after starting the new agent to allow time for it to be effective). All patients should undergo regular monitoring and follow-up so that, if needed, appropriate measures can be taken in a timely manner to offset unexpected toxicities or to treat suboptimal disease response, which is much more likely in patients already showing a lack of good treatment response to a first-line therapy. ${ }^{116}$

\section{ACKNOWLEDGMENTS}

Teva, the funding sponsor, offered unrestricted support to the development of the manuscript and did not have any part in creating this document. The funding also provided the authors with the services of an experienced and qualified medical writer to ensure a professional manuscript. The medical writer, solely under the direction and outline of the authors, assisted in researching the topic and preparing a first draft. At no time did the medical writer have any involvement in determining the content of the manuscript. The authors gratefully acknowledge the contribution of Radmila Day in the drafting of the manuscript.

\section{STATEMENT OF AUTHORSHIP}

MSF, PSG, AP, and DS participated in revising the manuscript critically for important intellectual content and approved the final version of the manuscript to be published.

\section{Disclosures}

MSF reports grants from Teva, during the conduct of the study; grants and personal fees from Genzyme, personal fees from Sanofi-Genzyme, personal fees from Actelion, personal fees from Bayer HealthCare, personal fees from Biogen Inc., personal fees from Chugai, personal fees from EMD Serono Canada Inc., personal fees from Hoffman La-Roche, personal fees from Merck Serono, personal fees from Novartis, personal fees from SanofiAventis, personal fees from Clene Nanomedicine, outside the submitted work. MSF has been a member of a company advisory board, board of directors, or another similar group for Acetlion, Bayer HealthCare, Biogen Inc., Hoffman La-Roche, Merck Serono, MedDay, Novartis, and Sanofi-Aventis; he also particpated in a Genzyme-sponsored speaker bureau.

PSG reports grants from Teva Canada Innovation, during the conduct of the study; grants and personal fees from Biogen Inc., grants and personal fees from Teva, grants from Alexion, grants and personal fees from Bayer HealthCare, grants from Elan, grants and personal fees from EMD Serono Canada Inc., grants from GlaxoSmithKline, grants from MedDay, grants and personal fees from Novartis, grants from Ono, grants and personal fees from Roche, grants from Sanofi-Aventis, personal fees from NeuroRx, personal fees from Allergan, personal fees from Sanofi-Genzyme, personal fees from Merz, outside the submitted work. PSG has acted as a principal investigator or sub-investigator for clinical trials for Alexion, Bayer HealthCare, Biogen Inc., Elan, EMD Serono Canada Inc., GaxoSmithKline, MedDay, Novartis, Ono, Roche-Genetech, Sanofi-Aventis, and Teva Neuroscience.

AP reports grants from Teva Canada Innovation, during the conduct of the study; personal fees from Teva, personal fees from EMD Serono Canada Inc., personal fees from Merck Serono, personal fees from Biogen Inc., personal fees from Sanofi-Genzyme, outside the submitted work. AP is also a senior Canada Research Chair in MS.
DS reports grants from Teva Canada Innovation, during the conduct of the study; personal fees from Merck Serono, personal fees and grants from Novartis, personal fees and grants from Roche, personal fees from Genzyme, personal fees from Teva, grants from Sanofi-Genzyme, personal fees from Biogen Inc., personal fees from Bayer HealthCare, outside the submitted work.

\section{REFERENCES}

1. Compston A, Coles A. Multiple sclerosis. Lancet. 2008;372(9648): 1502-17.

2. Frohman EM, Racke MK, Raine CS. Multiple sclerosis-the plaque and its pathogenesis. N Engl J Med. 2006;354(9):942-55.

3. Larochelle C, Alvarez JI, Prat A. How do immune cells overcome the blood-brain barrier in multiple sclerosis? FEBS Lett. 2011; 585(23):3770-80.

4. Broux B, Gowing E, Prat A. Glial regulation of the blood-brain barrier in health and disease. Semin Immunopathol. 2015;37(6): 577-90.

5. Freedman MS, Selchen D, Arnold DL. Treatment optimization in MS: Canadian MS Working Group updated recommendations. Can J Neurol Sci. 2013;40(3):307-23.

6. Gholipour T, Healy B, Baruch NF, Weiner HL, Chitnis T. Demographic and clinical characteristics of malignant multiple sclerosis. Neurology. 2011;76(23):1996-2001.

7. Menon S, Shirani A, Zhao Y, et al. Characterising aggressive multiple sclerosis. J Neurol Neurosurg Psychiatry. 2013;84(11): 1192-8.

8. Freedman MS, Rush CA. Severe, highly active, or aggressive multiple sclerosis. Continuum (Minneap Minn). 2016;22(3):761-84.

9. Rush CA, MacLean HJ, Freedman MS. Aggressive multiple sclerosis: proposed definition and treatment algorithm. Nat Rev Neurol. 2015;11(7):379-89.

10. Coles AJ, Twyman CL, Arnold DL, et al. Alemtuzumab for patients with relapsing multiple sclerosis after disease-modifying therapy: a randomised controlled phase 3 trial. Lancet. 2012;380 (9856):1829-39.

11. Giovannoni G, Comi G, Cook S, et al. A placebo-controlled trial of oral cladribine for relapsing multiple sclerosis. N Engl J Med. 2010;362(5):416-26

12. Weiner HL, Mackin GA, Orav EJ, et al. Intermittent cyclophosphamide pulse therapy in progressive multiple sclerosis. Neurology. 1993;43(5):910-8.

13. Noseworthy JH, Ebers GC, Gent TP, et al. The Canadian cooperative trial of cyclophosphamide and plasma exchange in progressive multiple sclerosis. Lancet. 1991;337:441-6.

14. Edan G, Comi G, Le Page E, et al. Mitoxantrone prior to interferon beta-1b in aggressive relapsing multiple sclerosis: a 3-year randomised trial. J Neurol Neurosurg Psychiatry. 2011;82(12): 1344-50.

15. Hauser SL, Bar-Or A, Comi G, et al. OPERA I and OPERA II clinical investigators ocrelizumab versus interferon beta-1a in relapsing multiple sclerosis. N Engl J Med. 2017;376(3): 221-34.

16. Johnson KP, Brooks BR, Cohen JA, et al. Copolymer 1 reduces relapse rate and improves disability in relapsing-remitting multiple sclerosis: results of a phase III multicenter, doubleblind placebo-controlled trial. The Copolymer 1 Multiple Sclerosis Study Group. Neurology. 1995;45(7):1268-76.

17. The IFNB Multiple Sclerosis Study Group. Interferon beta-1b is effective in relapsing-remitting multiple sclerosis. I. Clinical results of a multicenter, randomized, double-blind, placebocontrolled trial. Neurology. 1993;43(4):655-61.

18. Jacobs LD, Cookfair DL, Rudick RA, et al. Intramuscular interferon beta-1a for disease progression in relapsing multiple sclerosis. The Multiple Sclerosis Collaborative Research Group (MSCRG) avonox. Ann Neurol. 1996;39(3):285-94.

19. PRISMS (Prevention of Relapses and Disability by Interferon b-1a Subcutaneously in Multiple Sclerosis) Study Group. Randomized double-blind placebo-controlled study of interferon beta-1a in relapsing/remitting multiple sclerosis. Lancet. 1998;352: 1498-504. 
20. Kieseier BC, Arnold DL, Balcer LJ, et al. Peginterferon beta-1a in multiple sclerosis: 2-year results from ADVANCE. Mult Scler. 2015;21(8):1025-35.

21. O'Connor P, Wolinsky JS, Confavreux C. Placebo-controlled phase 3 study of oral BG-12 for relapsing multiple sclerosis. N Engl J Med. 2012;367(12):1098-107.

22. Cohen JA, Barkhof F, Comi G, et al. Oral fingolimod or intramuscular interferon for relapsing multiple sclerosis. N Engl J Med. 2010;362(5):402-15.

23. O'Connor P, Wolinsky JS, Confavreux C, et al. Randomized trial of oral teriflunomide for relapsing multiple sclerosis. N Engl J Med. 2011;365(14):1293-303.

24. Kappos L, Wiendl H, Selmaj K, et al. Daclizumab HYP versus interferon beta-1a in relapsing multiple sclerosis. N Engl J Med. 2015;373(15):1418-28.

25. Chris HP, Randomized A. Placebo-controlled trial of natalizumab for relapsing multiple sclerosis. N Engl J Med. 2011;365(14): 1293-303.

26. Gajofatto A, Benedetti MD. Treatment strategies for multiple sclerosis: when to start, when to change, when to stop? World J Clin Cases. 2015;3(7):545-55.

27. Warnke C, Olsson T, Hartung HP. PML: the dark side of immunotherapy in multiple sclerosis. Trends Pharmacol Sci. 2015; 36(12):799-801.

28. Outteryck O. Natalizumab in relapsing-remitting multiple sclerosis. Expert Rev Neurother. 2016;16(5):471-81

29. Freedman MS1, Wolinsky JS, Wamil B, et al. Teriflunomide added to interferon- $\beta$ in relapsing multiple sclerosis: a randomized phase II trial. Neurology. 2012;78(23):1877-85.

30. Farina C, Weber MS, Meinl E, Wekerle H, Hohlfeld R. Glatiramer acetate in multiple sclerosis: update on potential mechanisms of action. Lancet Neurol. 2005;4(9):567-75.

31. Aharoni R. Immunomodulation neuroprotection and remyelination the fundamental therapeutic effects of glatiramer acetate: a critical review. J Autoimmun. 2014;54:81-92.

32. Lalive $\mathrm{PH}$, Neuhaus $\mathrm{O}$, Benkhoucha $\mathrm{M}$, et al. Glatiramer acetate in the treatment of multiple sclerosis: emerging concepts regarding its mechanism of action. CNS Drugs. 2011;25(5):401-14.

33. Cohen JA, Chun J. Mechanisms of fingolimod's efficacy and adverse effects in multiple sclerosis. Ann Neurol. 2011;69(5): 759-77.

34. Chun J, Hartung HP. Mechanism of action of oral fingolimod (FTY720) in multiple sclerosis. Clin Neuropharmacol. 2010;33(2): 91-101.

35. Comi G, Amato MP, Bertolotto A, et al. The heritage of glatiramer acetate and its use in multiple sclerosis. Mult Scler Demyelinating Disord. 2016;1:6.

36. Lazibat I, Nevajda B, Grahovac G, Brinar VV. Should MS be treated by escalation or induction therapy? Coll Antropol. 2014;38(1): 385-93.

37. Cornaby C, Gibbons L, Mayhew V, et al. B cell epitope spreading: mechanisms and contribution to autoimmune diseases. Immunol Lett. 2015;163(1):56-68.

38. Morrissey SP, Le Page E, Edan G. Mitoxantrone in the treatment of multiple sclerosis. Int MS J. 2005;12:74-87.

39. Le Page E, Leray E, Taurin G, et al. Mitoxantrone as induction treatment in aggressive relapsing remitting multiple sclerosis: treatment response factors in a 5 year follow-up observational study of 100 consecutive patients. J Neurol Neurosurg Psychiatry. 2008;79(1):52-6.

40. Edan G, Comi G, Le Page E, et al. Mitoxantrone prior to interferon beta-1b in aggressive relapsing multiple sclerosis: a 3-year randomised trial. J Neurol Neurosurg Psychiatry. 2011;82(12): 1344-50.

41. Vollmer T, Panitch H, Bar-Or A, et al. Glatiramer acetate after induction therapy with mitoxantrone in relapsing multiple sclerosis. Mult Scler. 2008;14(5):663-70.

42. Minagar A, Alexander JS, Sahraian MA, et al. Alemtuzumab and multiple sclerosis: therapeutic application. Expert Opin Biol Ther. 2010;10(3):421-9.

43. Havrdova E, Horakova D, Kovarova I. Alemtuzumab in the treatment of multiple sclerosis: key clinical trial results and considerations for use. Ther Adv Neurol Disord. 2015;8(1):31-45.
44. Cossburn M, Pace AA, Jones J, et al. Autoimmune disease after alemtuzumab treatment for multiple sclerosis in a multicenter cohort. Neurology. 2011;77(6):573-9.

45. Hill-Cawthorne GA, Button $\mathrm{T}$, Tuohy $\mathrm{O}$, et al. Long term lymphocyte reconstitution after alemtuzumab treatment of multiple sclerosis. J Neurol Neurosurg Psychiatry. 2012;83(3): 298-304.

46. Dayan C, Cuker A, LaGanke C, et al. Autoimmunity in patients treated with alemtuzumab for relapsing-remitting multiple sclerosis: 5-year follow-up of the CARE-MS studies. Presented at ECTRIMS, ECTRIMS 14-17 September, 2016, London, United Kingdom, Presentation No. O168.

47. Le Page E, Deburghgraeve V, Lester MA, Cardiet I, Leray E, Edan G. Alemtuzumab as rescue therapy in a cohort of 16 aggressive multiple sclerosis patients previously treated by Mitoxantrone: an observational study. J Neurol. 2015;262(4):1024-34.

48. Patti F, Lo Fermo S. Lights and shadows of cyclophosphamide in the treatment of multiple sclerosis. Autoimmune Dis. 2011; 2011:961702.

49. Awad A, Stüve O. Cyclophosphamide in multiple sclerosis: scientific rationale, history and novel treatment paradigms. Ther Adv Neurol Disord. 2009;2(6):50-61.

50. Lugaresi A, di Ioia M, Travaglini D, Pietrolongo E, Pucci E, Onofrj M. Risk-benefit considerations in the treatment of relapsingremitting multiple sclerosis. Neuropsychiatr Dis Treat. 2013;9: 893-914.

51. Martinelli V, Cocco E, Capra R, et al. Acute myeloid leukemia in Italian patients with multiple sclerosis treated with mitoxantrone. Neurology. 2011;77:1887-995.

52. Patti F, Lo Fermo S. Lights and shadows of cyclophosphamide in the treatment of multiple sclerosis. Autoimmune Dis. 2011; 2011:961702.

53. D'Amico E, Zanghì A, Leone C, Tumani H, Patti F. Treatmentrelated progressive multifocal leukoencephalopathy in multiple sclerosis: a comprehensive review of current evidence and future needs. Drug Saf. 2016;39(12):1163-74.

54. Biogen Idec Canada Inc. ${ }^{\text {Pr}}$ TECFIDERA ${ }^{\mathrm{TM}}$ product monograph, January 29, 2015.

55. Gyang TV, Hamel J, Goodman AD, Gross RA, Samkoff L. Fingolimod-associated PML in a patient with prior immunosuppression. Neurology. 2016;86(19):1843-5.

56. Spurgeon S, Yu M, Phillips JD, Epner EM. Cladribine: not just another purine analogue? Expert Opin Investig Drugs. 2009; 18(8):1169-81.

57. Sipe JC1. Cladribine for multiple sclerosis: review and current status. Expert Rev Neurother. 2005;5(6):721-7.

58. Liliemark J. The clinical pharmacokinetics of cladribine. Clin Pharmacokinet. 1997;32(2):120-31.

59. Giovannoni G, Comi G, Cook S, et al. A placebo-controlled trial of oral cladribine for relapsing multiple sclerosis. N Engl J Med. 2010;362(5):416-26.

60. Cook S, Vermersch P, Comi G, et al. CLARITY Study Group Safety and tolerability of cladribine tablets in multiple sclerosis: the CLARITY (CLAdRIbine Tablets treating multiple sclerosis orallY) study. Mult Scler. 2011;17(5):578-93.

61. Martinez-Rodriguez JE, Cadavid D, Wolansky LJ, Pliner L, Cook SD. Cladribine in aggressive forms of multiple sclerosis. Eur J Neurol. 2007;14(6):686-9.

62. Gandey A. FDA rejects oral cladribine for multiple sclerosis. Medscape. March 2, 2011.

63. Pakpoor J, Disanto G, Altmann DR, et al. No evidence for higher risk of cancer in patients with multiple sclerosis taking cladribine. Neurol Neuroimmunol Neuroinflamm. 2015;2(6):e158.

64. Giovannoni G, Comi G, Cook S, et al. Durable efficacy of cladribine tablets in patients with multiple sclerosis: analysis of relapse rates and relapse-free patients in the CLARITY and CLARITY extension studies Congress of the European Committee for Treatment and Research in Multiple Sclerosis (ECTRIMS) 2016. Abstract 164, Presented on September 14-16, 2016.

65. Brooks M. Cladribine (Mavenclad) for MS approved in Europe. Available at http://www.medscape.com/viewarticle/884703. Accessed October 09, 2017. 
66. Government of Canada. Notice of compliance information. Available at https://health-products.canada.ca/noc-ac/info.do? lang $=$ en\&no=20099. Accessed December 18, 2017.

67. Fenu G, Lorefice L, Frau F, Coghe GC, Marrosu MG, Cocco E. Induction and escalation therapies in multiple sclerosis. Antiinflamm Antiallergy Agents Med Chem. 2015;14(1):26-34.

68. Ziemssen T, Derfuss T, de Stefano N, et al. Optimizing treatment success in multiple sclerosis. J Neurol. 2016;263(6):1053-65.

69. Du Pasquier RA, Pinschewer DD, Merkler D. Immunological mechanism of action and clinical profile of disease-modifying treatments in multiple sclerosis. CNS Drugs. 2014;28(6): 535-58.

70. Kieseier BC, Jeffery DR. Chemotherapeutics in the treatment of multiple sclerosis. Ther Adv Neurol Disord. 2010;3(5):277-91.

71. Bhargava P, Newsome SD. An update on the evidence base for peginterferon $\beta 1 \mathrm{a}$ in the treatment of relapsing-remitting multiple sclerosis. Ther Adv Neurol Disord. 2016;9(6):483-90.

72. Khan O, Rieckmann P, Boyko A, et al. Efficacy and safety of a threetimes-weekly dosing regimen of glatiramer acetate in relapsingremitting multiple sclerosis patients: 3-year results of the Glatiramer Acetate Low-Frequency Administration open-label extension study. Mult Scler. 2017;23(6):818-29.

73. Phillips JT, Hutchinson M, Fox R, Gold R, Havrdova E. Managing flushing and gastrointestinal events associated with delayedrelease dimethyl fumarate: experiences of an international panel. Mult Scler Relat Disord. 2014;3(4):513-9.

74. Gold R, Kappos L, Arnold DL, et al. Placebo-controlled phase 3 study of oral BG-12 for relapsing multiple sclerosis. N Engl J Med. 2012;367(12):1098-107.

75. Kappos L, Gold R, Miller DH, et al. Efficacy and safety of oral fumarate in patients with relapsing-remitting multiple sclerosis: a multicentre, randomised, double-blind, placebo-controlled phase IIb study. Lancet. 2008;372(9648):1463-72.

76. Kappos L, Gold R, Miller DH, et al. Efficacy and safety of oral fumarate in patients with relapsing-remitting multiple sclerosis: a multicentre, randomised, double-blind, placebo-controlled phase IIb study. Lancet. 2008;372(9648):1463-72.

77. Garnock-Jones KP. Teriflunomide: a review of its use in relapsing multiple sclerosis. CNS Drugs. 2013;27(12):1103-23.

78. Burness CB, Deeks ED. Dimethyl fumarate: a review of its use in patients with relapsing-remitting multiple sclerosis. CNS Drugs. 2014;28(4):373-87.

79. Curtin F, Hartung HP. Novel therapeutic options for multiple sclerosis. Expert Rev Clin Pharmacol. 2014;7(1):91-104.

80. Nieuwkamp DJ, Murk JL, van Oosten BW, et al. PML in a patient without severe lymphocytopenia receiving dimethyl fumarate. N Engl J Med. 2015;372(15):1474-6.

81. Longbrake EE, Naismith RT, Parks BJ, et al. Dimethyl fumarateassociated lymphopenia: risk factors and clinical significance. Mult Scler J Exp Transl Clin 2015;1:1-8.

82. Brück W, Gold R, Lund BT, et al. Therapeutic decisions in multiple sclerosis: moving beyond efficacy. JAMA Neurol. 2013;70(10): 1315-24.

83. Schwid SR, Panitch HS. Full results of the Evidence of Interferon Dose-Response-European North American Comparative Efficacy (EVIDENCE) study: a multicenter, randomized, assessor-blinded comparison of low-dose weekly versus high-dose, high-frequency interferon beta-1a for relapsing multiple sclerosis. Clin Ther. 2007;29(9):2031-48

84. CAMMS223 Trial Investigators. Alemtuzumab vs. interferon beta-1a in early multiple sclerosis. N Engl J Med. 2008;359(17): 1786-801

85. Hauser SL, Bar-Or A, Comi G, et al. Ocrelizumab versus interferon beta-1a in relapsing multiple sclerosis. N Engl J Med. 2017;376(3): 221-34.

86. Putzki N, Yaldizli O, Buhler R, et al. Natalizumab reduces clinical and MRI activity in multiple sclerosis patients with high disease activity: results from a multicenter study in Switzerland. Eur Neurol. 2010;63(2):101-6.

87. Spelman T, Kalincik T1, Zhang A, et al. Comparative efficacy of switching to natalizumab in active multiple sclerosis. Ann Clin Transl Neurol. 2015;2(4):373-87.
88. Prosperini L, Gianni C, Leonardi L, et al. Escalation to natalizumab or switching among immunomodulators in relapsing multiple sclerosis. Mult Scler. 2012;18(1):64-71.

89. Castillo-Trivino T, Mowry EM, Gajofatto A, et al. Switching multiple sclerosis patients with breakthrough disease to second line therapy. PLoS One. 2011;6(2):e16664.

90. Krysko KM, OConnor PW. The Toronto observational study of natalizumab in multiple sclerosis. Can J Neurol Sci. 2011;38(3): 422-8.

91. Khatri B, Barkhof F, Comi G, et al. Comparison of fingolimod with interferon beta-1a in relapsing-remitting multiple sclerosis: a randomised extension of the TRANSFORMS study. Lancet Neurol. 2011;10(6):520-9.

92. Baroncini D, Ghezzi A, Annovazzi PO, et al. Natalizumab versus fingolimod in patients with relapsing-remitting multiple sclerosis non-responding to first-line injectable therapies. Mult Scler. 2016;22(10):1315-26.

93. Carruthers RL, Rotstein DL, Healy BC, et al. An observational comparison of natalizumab vs. fingolimod using JCV serology to determine therapy. Mult Scler. 2014;20(10):1381-90.

94. Gajofatto A, Bianchi MR, Deotto L, et al. Are natalizumab and fingolimod analogous second-line options for the treatment of relapsing-remitting multiple sclerosis? A clinical practice observational study. Eur Neurol. 2014;72(3-4):173-80.

95. Kalincik T, Horakova D, Spelman T, et al. Switch to natalizumab versus fingolimod in active relapsing remitting multiple sclerosis. Ann Neurol. 2015;77(3):425-35.

96. Kalincik T, Brown JW, Robertson N, et al. Treatment effectiveness of alemtuzumab compared with natalizumab, fingolimod, and interferon beta in relapsing-remitting multiple sclerosis: a cohort study. Lancet Neurol. 2017;16(4):271-81.

97. Montalban X, Hauser SL, Kappos L, et al. Ocrelizumab versus placebo in primary progressive multiple sclerosis. N Engl J Med. 2017;376(3):209-20

98. Health Canada approves ocrelizumab for the management of relapsing-remitting MS. Available at https://mssociety. ca/research-news/article/health-canada-approves-ocrelizumab-forthe-management-of-relapsing-remitting-ms. Accessed October 09, 2017.

99. Shirley M. Daclizumab: a review in relapsing multiple sclerosis. Drugs. 2017;77(4):447-58.

100. Brooks M. EMA restricts use of daclizumab (zinbryta) in MS. Available at http://www.medscape.com/viewarticle/ 882607. Accessed March 7, 2018.

101. Biogen Canada Inc. ${ }^{\mathrm{Pr}}$ ZINBRYTA ${ }^{\mathrm{TM}}$ product monograph, December 16, 2016.

102. Brooks M. MS drug daclizumab (zinbryta) pulled from the market. Available at https://www.medscape.com/viewarticle/893352. Accessed March 12, 2018.

103. Biogen Canada. TYSABRI ${ }^{\circledR}$ PML Quarterly Update - December 2017 (internal document).

104. Bloomgren G, Richman S, Hotermans C, et al. Risk of natalizumabassociated progressive multifocal leukoencephalopathy. N Engl J Med. 2012;366(20):1870-80.

105. Plavina T, Subramanyam M, Bloomgren G, et al. Anti-JC virus antibody levels in serum or plasma further define risk of natalizumab-associated progressive multifocal leukoencephalopathy. Ann Neurol. 2014;76(6):802-12.

106. Killestein J, Vennegoor A, van Golde AEL, et al. PML-IRIS during fingolimod diagnosed after natalizumab discontinuation. Case Rep Neurol Med. 2014;2014:307872.

107. Giovannoni G, Marta M, Davis A, et al. Switching patients at high risk of PML from natalizumab to another disease-modifying therapy. Pract Neurol. 2016;16(5):389-93.

108. Martinelli V, Colombo B, Dalla Costa G, et al. Recurrent disease-activity rebound in a patient with multiple sclerosis after natalizumab discontinuations for pregnancy planning. Mult Scler. 2016;22(11):1506-8.

109. Larochelle C, Metz I, Lécuyer MA, et al. Immunological and pathological characterization of fatal rebound MS activity following natalizumab withdrawal. Mult Scler. 2017;23(1): $72-81$. 
110. Borriello G, Prosperini L, Mancinelli C, et al. Pulse monthly steroids during an elective interruption of natalizumab: a post-marketing study. Eur J Neurol. 2012;19(5):783-7.

111. Evangelopoulos ME, Koutoulidis V, Andreadou E, et al. Pulsed corticosteroid treatment in MS patients stabilizes disease activity following natalizumab withdrawal prior to switching to fingolimod. Int J Neurosci. 2016;126(12):1097-102.

112. Fragoso YD, Adoni T, Alves-Leon SV, et al. Alternatives for reducing relapse rate when switching from natalizumab to fingolimod in multiple sclerosis. Expert Rev Clin Pharmacol. 2016;21:1-6.

113. Cohan S, Edwards K, Chen C, et al. Rebound disease activity reduction in relapsing multiple sclerosis patients transitioned from natalizumab to teriflunomide. Presented at ECTRIMS, ECTRIMS 14-17 September, 2016, London, United Kingdom, Poster No. P655.

114. Cutter GR, Stüve O. Does risk stratification decrease the risk of natalizumab-associated PML? Where is the evidence? Mult Scler. 2014;20(10):1304-5

115. Mowry EM, McArthur JC. PML in natalizumab-treated multiple sclerosis: modeling errors and risk miscalculations. Neurology. 2017;88(12):1110-1.

116. Antel J. Mechanisms of action of fingolimod in multiple sclerosis. Clin Exp Neuroimmunol. 2014;5:49-54.

117. Hu Y, Turner MJ, Shields J, et al. Investigation of the mechanism of action of alemtuzumab in a human CD52 transgenic mouse model. Immunology. 2009;128(2):260-70.

118. Johnson TA, Shames I, Keezer M, et al. Reconstitution of circulating lymphocyte counts in FTY720-treated MS patients. Clin Immunol. 2010;137(1):15-20.

119. Amato MP, Portaccio E, Ghezzi A, et al. Pregnancy and fetal outcomes after interferon-beta exposure in multiple sclerosis. Neurology. 2010;75:1794-802.

120. Giannini M, Portaccio E, Ghezzi A, et al. Pregnancy and fetal outcomes after glatiramer acetate exposure in patients with multiple sclerosis: a prospective observational multicentric study. BMC Neurol. 2012;12:124.

121. Lu E, Wang BW, Guimond C, et al. Safety of disease modifying drugs for multiple sclerosis in pregnancy: current challenges and future considerations for effective pharmacovigilance. Expert Rev Neurother. 2013;13:251-60.

122. De Giglio L, Gasperini C, Tortorella C, Trojano M, Pozzilli C. Natalizumab discontinuation and disease restart in pregnancy: a case series. Acta Neurol Scand. 2015;131:336-40.

123. O'Connor PW, Li D, Freedman MS, et al. A phase II study of the safety and efficacy of teriflunomide in multiple sclerosis with relapses. Neurology. 2006;66(6):894-900.

124. FDA Pregnancy Categories: FDA pregnancy risk information: an update. Available at https://www.drugs.com/pregnancy-categories. $\mathrm{html}$. Accessed September 13, 2017.

125. Genzyme Canada, a division of sanofi-aventis Canada Inc. ${ }^{\mathrm{Pr}} \mathrm{AU}$ BAGIO $^{\text {TM }}$ product monograph, November 12, 2013.

126. Henson LJ, Stuve O, Kieseier B, Benamor M, Benzerdjeb MH. Pregnancy outcomes from the teriflunomide clinical development program: retrospective analysis of the teriflunomide clinical trial database (S30.005). Neurology. 2013;80(7 Suppl):S30.005.

127. Vukusic S, Coyle PK, Jurgensen S, et al. Pregnancy outcomes in patients with MS treated with teriflunomide: clinical study and post-marketing data. ECTRIMS 2017, Abstract 205.

128. Traboulsee A, Simon JH, Stone L, et al. Revised recommendations of the consortium of MS centers task force for a standardized MRI protocol and clinical guidelines for the diagnosis and followup of multiple sclerosis. AJNR Am J Neuroradiol. 2016;37(3): 394-401.

129. Haars S, Schmidt R, Orthgieß J, et al. Alterations of serum lipid profile in multiple sclerosis patients treated with fingolimod. Presented at ECTRIMS, ECTRIMS 14-17 September, 2016, London, United Kingdom, Poster No. P718.

130. Stecchi S, Scandellari C, Gabrielli L, Lazzarotto T. Recommendations for fingolimod treated patients vaccinated for Varicella zoster virus. Neurology. 2014;82(10 Suppl):P7.217.
131. Rudnicka J, Czerwiec M, Grywalska E, et al. Influence of fingolimod on basic lymphocyte subsets frequencies in the peripheral blood of multiple sclerosis patients - preliminary study. Cent Eur J Immunol. 2015;40(3):354-9.

132. Ward MD, Jones DE, Goldman MD. Cryptococcal meningitis after fingolimod discontinuation in a patient with multiple sclerosis. Mult Scler Relat Disord. 2016;9:47-9.

133. Gilenya (fingolimod) capsules $0.5 \mathrm{mg}$. Available at http://www. fda.gov/Safety/MedWatch/SafetyInformation/ucm266123.htm. Accessed January 17, 2017.

134. Spelman T, Mekhael L, Burke T, et al. Risk of early relapse following the switch from injectables to oral agents for multiple sclerosis. Eur J Neurol. 2016;23(4):729-36.

135. Hassoun L, Eisele J, Thomas K, Ziemsse $T$. Hands on alemtuzumab-experience from clinical practice: whom and how to treat. Mult Scler Demyelinat Disord. 2016;1:10.

136. Willis M, Pearson O, Illes Z, et al. Multiple sclerosis disease rebound after treatment switch from fingolimod to alemtuzumab. Presented at ECTRIMS, ECTRIMS 14-17 September, 2016, London, United Kingdom, Poster No. P1258.

137. Fox RJ, Kita M, Cohan SL, et al. BG-12 (dimethyl fumarate): a review of mechanism of action, efficacy, and safety. Curr Med Res Opin. 2014;30(2):251-62.

138. Miller AE. Switching or discontinuing disease-modifying therapies for multiple sclerosis. Continuum (Minneap Minn). 2016;22(3): 851-63.

139. Polman CH, O'Connor PW, Havrdova E, et al. A randomized, placebo-controlled trial of natalizumab for relapsing multiple sclerosis. N Engl J Med. 2006;354(9):899-910.

140. Gallo P, Van Wijmeersch B. Overview of the management of relapsing-remitting multiple sclerosis and practical recommendations. Eur J Neurol. 2015;22(Suppl 2):14-21.

141. Cliford DB. PML risk in MS therapeutics. ECTRIMS 2017, Abstract 202.

142. Clerico M, Schiavetti I, De Mercanti SF, et al. Treatment of relapsing-remitting multiple sclerosis after 24 doses of natalizumab: evidence from an Italian spontaneous, prospective, and observational study (the TY-STOP Study). JAMA Neurol. 2014;71(8):954-60.

143. Cohen M, Maillart E, Tourbah A, et al. Switching from natalizumab to fingolimod in multiple sclerosis: a French prospective study. JAMA Neurol. 2014;71:436-41.

144. Fox RJ, Cree BA, De Seze J, et al. MS disease activity in RESTORE: a randomized 24-week natalizumab treatment interruption study. Neurology. 2014;82:1491-8.

145. Sinnecker T, Othman J, Kühl M, et al. Progressive multifocal leukoencephalopathy in a multiple sclerosis patient diagnosed after switching from natalizumab to fingolimod. Case Rep Neurol Med. 2016;2016:5876798.

146. Putzki N. Characteristics of PML cases in multiple sclerosis patients switching to fingolimod from natalizumab. ECTRIMS. 2014; FC3.1.

147. Houtchens MK, Kolb CM. Multiple sclerosis and pregnancy: therapeutic considerations. J Neurol. 2013;260:1202-14.

148. Hatcher SE, Waubant E, Nourbakhsh B, Crabtree-Hartman E, Graves JS. Rebound syndrome in patients with multiple sclerosis after cessation of fingolimod treatment. JAMA Neurol. 2016;73(7): 790-4.

149. Faissner S, Hoepner R, Lukas C, Chan A, Gold R, Ellrichmann G. Tumefactive multiple sclerosis lesions in two patients after cessation of fingolimod treatment. Ther Adv Neurol Disord. 2015;8(5):233-8.

150. Salam S, Mihalova T, Siripurapu R. Severe tumefactive rebound of multiple sclerosis following fingolimod cessation. BMJ Case Rep. 2016;2016:pii: bcr2016215596.

151. Freedman MS, Wolinsky JS, Wamil B, et al. Teriflunomide added to interferon- $\beta$ in relapsing multiple sclerosis: a randomized phase II trial. Neurology. 2012;78(23):1877-85.

152. Goodman AD, Rossman H, Bar-Or A, et al. GLANCE: results of a phase 2, randomized, double-blind, placebo-controlled study. Neurology. 2009;72(9):806-12. 